\title{
Business service networks and their process of emergence: The case of the Health Cluster Portugal ${ }^{\text {光 }}$
}

\author{
Carla Ramos ${ }^{\mathrm{a}, \mathrm{b}, *}$, Catarina Roseira ${ }^{\mathrm{c}}$, Carlos Brito ${ }^{\mathrm{c}}$, Stephan C. Henneberg ${ }^{\mathrm{b}}$, Peter Naudé ${ }^{\mathrm{b}}$ \\ a Insper Institute of Education and Research, Rua Quatá, 300, Vila Olimpia, 04546-042 São Paulo, SP, Brazil \\ b mIMP Research Group, Manchester Business School, University of Manchester, Booth Street West, Manchester United Kingdom \\ ${ }^{\text {c }}$ Faculdade de Economia do Porto, Universidade do Porto, Rua Roberto Frias, Porto Portugal
}

\section{A R T I C L E I N F O}

\section{Article history:}

Received 1 January 2012

Received in revised form 1 October 2012

Accepted 1 January 2013

Available online 15 June 2013

\section{Keywords:}

Business service network

Industrial Network Approach

Emergence of networks

Health Cluster Portugal

\begin{abstract}
A B S T R A C T
Business services have been receiving increasing attention from academics, practitioners and policy-makers. Despite the growing interest, this field of research suffers from several limitations: it draws mostly on services marketing theory, and it is grounded mostly in monadic and dyadic studies. This paper contributes to the advance of business services research by addressing these limitations with regard to a specific service-related issue. We carry out an interdisciplinary study by integrating among others an industrial network approach (INA) into the services area, and we thus develop the research at a network level by adopting a services network perspective; furthermore, the study is carried out in a business-to-business context by looking into a health cluster: the Health Cluster Portugal. The article addresses one particular aspect of business services networks: their emergence. We propose a conceptual framework that draws on process-based research and integrates theories from other bodies of research, allowing a rich understanding of how a business service network is created. Our findings point to discontinuities along the emergence of such networks, showing that there is an iterative process underlying their formation, with different theories playing a predominant explanatory role at different stages. This paper contributes to the wider body of literature on services research by promoting the integration of the INA and other process-related approaches in the area of business services networks, and also provides practitioners and policy-makers with a structured framework to understand how an intentional 'bottom-up' business service network may be created or orchestrated.
\end{abstract}

(c) 2013 Elsevier Inc. All rights reserved.

\section{Introduction}

It is becoming increasingly difficult to ignore the dominance of the services sector (Armistead \& Machin, 1998; Bitner \& Brown, 2008), considered a building block for the world's strongest economies and a priority area for growth for the current decade (Edvardsson, Gustafsson, \& Enquist, 2006; Spohrer \& Maglio, 2008). As a result, since its establishment as an academic discipline in the late 1980s, there has been a strong interest in service research (Rust, 2004), with special focus on service quality and customer service satisfaction (Jamal \& Anastasiadou, 2009; Parasuraman, Zeithaml, \& Berry, 1988, 1994; Pilkington \& Chai, 2008). Related to these two research areas, and representing the current emphasis in the field (Pilkington \& Chai, 2008), there are foci on the service profit chain (Heskett, Jones, Loveman, Sasser, \& Schlesinger, 1994; Heskett \& Sasser, 2010), customer services relationships (Liljander \& Strandvik, 1995; Ramaseshan, Bejou, Jain, Mason, \& Pancras, 2006), return on service quality (Mittal, Anderson, Sayrak, \& Tadikamalla, 2005; Rust \&

\footnotetext{
is Acknowledgment of financial assistance: This project was funded by the British Academy (Ref. SG100451).

* Corresponding author. Tel.: + 441613063464

E-mail address: carla.ramos@mbs.ac.uk (C. Ramos).
}

Zahoril, 1993), service encounters (Piyush, Jackie, \& Namwoon, 2009; Shostack, 1985), and service recovery (Tax, Brown, \& Chandrashekaran, 1998; Vázquez-Casielles, Álvarez, \& Martín, 2010).

However, despite scholars' research focus on the wider services area, a more limited interest exists in service innovations and business services. This led Bitner and Brown (2008) to appeal for a "service imperative" (p. 73), reflecting the need to concentrate on growth and innovation through business services as a way to guarantee companies' and nations' global competitiveness. Adding to this, Spohrer and Maglio (2008) argued that service innovation is increasingly a pivotal demand in today's economies. In this context, it has been argued that what is lacking in this area of research are integrative approaches, putting less emphasis on services marketing theory utilizing monadic or dyadic analyses in a business-to-consumer contexts (Morgan, Deeter-Schmelz, \& Moberg, 2007; Ostrom et al., 2010; Pilkington \& Chai, 2008). Scholars are now appealing for further research to use interdisciplinary approaches which look at the wider (network) context, especially in business-to-business contexts (Bitner \& Brown, 2006; Ostrom et al., 2010; Spohrer, Maglio, Bailey, \& Gruhl, 2007). Moreover, drawing on the service-dominant logic (SDL; Vargo \& Lusch, 2004) and on the increasing interdisciplinary nature of service science, there is a call for a clearer system-based approach in service science (Maglio \& Spohrer, 
2008; Normann, 2001; Spohrer et al., 2007). Service systems are defined as "value co-creation configurations of people, technology, value propositions connecting internal and external service systems, and shared information (e.g. language, laws, measures and methods" (Maglio \& Spohrer, 2008, p. 18); management in such service systems needs to be based on a rigorous understanding of the underlying processes and mechanisms (Spohrer \& Maglio, 2008). Business networks of companies and their relationships (Håkansson et al., 2009; Jarillo, 1988; Nohria \& Eccles, 1992; Scott, 2000) can be described as a form of complex (adaptive) systems (Easton, Wilkinson, \& Georgieva, 1997; Ritter, Wilkinson, \& Johnston, 2004). These networks encompass social and economic actors, who are interconnected by varied links, such as economic, social, technical, logistic, administrative, informational, legal, and temporal links (Mattsson, 1988) that allow them to transform or exchange resources of financial, human, organizational or relational nature (Hunt \& Morgan, 1995). To understand such complex business networks, several approaches have been proposed, namely the strategic approach (Gulati, Nohria, \& Zaheer, 2000), the inter-organizational social network approach (Granovetter, 1973), and the industrial network approach (INA; Axelsson \& Easton, 1992).

Responding to the call for the use of interdisciplinary and system-based approaches in business-to-business service contexts, this article contributes to the advance of services research through utilizing the industrial network approach in a business services network setting. More specifically, we adopt the INA, together with social science and network theory, as well as inter-organizational cluster research, to understand the emergence of a specific business service network in the health sector: the Health Cluster Portugal (HCP).

The HCP was set up as a national cluster which is dominated by a services logic, specifically by trying to provide improved welfare in the area of public health through services, product-based solutions, and process innovations (Health Cluster Portugal, 2009a, 2009b). The improvement of well-being represents an area in services research which has also been identified as a neglected priority and requiring further investigation (Ostrom et al., 2010); from this rationale we derive the motivation for choosing the particular services network of the HCP as our focal case study for this research. By examining the creation of the HCP, we identify five developmental stages as well as associated iterative processes that describe distinct and yet temporally overlapping development phases. Findings show that the HCP services network emergence is characterized by discontinuities during which shaping and priming functions take place. Moreover, instead of a 'big bang' emergence (as envisaged by the founding members), a 'creationist' development model is shown to be a more appropriate perspective on the emergence of this particular services network. In this context, the industrial network approach, which was developed for industrial and product-based systemic environments, is found to provide appropriate insights for understanding the characteristics of each identified stage in the creation process. Furthermore, social sciences and network theories, as well as insights from cluster research, allow for a detailed understanding of the development processes, such as the transitions between stages of creation.

This article therefore contributes to the development of services research, providing empirical support for the benefits of applying a system-based view (the industrial network approach), as well as theories from other bodies of research, to carry out investigations in the services area. Additionally, it sheds some light on the scattered and ambiguous literature on what a business service network encompasses. Moreover, it provides practitioners with a better understanding of how a (bottomup) business service network can be formed. Policy-makers may also find it interesting to understand the dynamics underlying such a creation process, especially given the growing importance and implementation of collective services policies across several countries (Cooke, 2002).

The article is structured as follows: we begin by exploring the notion of business service networks, identifying these as an area of increasing importance. This is followed by a literature review on the process of emergence of business networks and clusters. The conceptual framework for the analysis of the emergence process of business service networks is then presented. This framework draws on the INA, as well as on theories from social sciences (including other network theories beyond the INA) and from cluster research. A section on the methodology for the empirical research follows. After presenting the case (the Health Cluster Portugal), the main findings are outlined. Finally, and following a discussion section, the main conclusions and contributions from this paper are presented, and its limitations and future research are identified.

\section{Research in business service networks}

In this section, we begin by reviewing existing research in services research, carried out on a monadic or dyadic level in business-to-consumer contexts. We point out that despite a shift in the research perspective in services research, more needs to be done; we back up this claim with recent calls for further research in business service networks. This is followed by a brief review of some relevant research that has been carried out in this area, and we offer a definition for business service networks that is adopted in this paper.

\subsection{Business service networks - an emerging area of research}

The services literature traditionally draws on a monadic or dyadic approach of service relationships, focusing on either a service provider or an interaction perspective of value (co-)creation (Ballantyne \& Varey, 2006; Ford, 2011; Payne, Storbacka, \& Frow, 2008). Moreover, it is recognized that service research has conventionally been developed in business-to-consumer exchange environment (Morgan et al., 2007; Ostrom et al., 2010; Pilkington \& Chai, 2008). Initial research on service networks has also been carried out in business-to-consumer contexts (Morgan, 2004). However, more recently service researchers have advocated (and partially adopted) a network and businessto-business approach, thereby focusing research on business service networks.

Several definitions for business networks can be found in the literature (Granovetter, 1992; Jarillo, 1988; Nohria, 1992; Uzzi, 1997). For this research project, we draw mostly on the INA developed by the Industrial Marketing and Purchasing (IMP) Group, and utilize a broad definition of networks (Håkansson \& Johanson, 1992; Johanson \& Mattsson, 1992). However, we also integrate in this investigation findings from other bodies of research on business networks mentioned above, namely literature on strategic nets (Gulati \& Gargiulo, 1999; Gulati et al., 2000), and inter-firm social networks (Granovetter, 1973; Scott, 2000; Uzzi, 1997). The INA assumes nevertheless a central part in our conceptual development, namely to understand the morphological characteristics of a business service network in its several stages of development.

According to the INA approach, the network is organic by nature, and it is used as a metaphor to understand the dynamics of business systems (Easton, 1992). Such networks cannot be managed by any single actor, and actors cannot choose to be or not be part of these networks; rather they are embedded in them via their direct and indirect business relationships. Such complex interconnected exchange relationships create a network, and it is through networking activities (i.e., strategic decisions and actions) that companies manage their position within the network which will allow them to mobilize and get access to other companies' resources (Ford \& Håkansson, 2006; Håkansson \& Snehota, 1989; Håkansson et al., 2009).

Services-related conceptualizations take into account that in order to be able to address increasing customer demands, providers are engaging in collaboration or joint-production agreements with other providing firms (Cravens \& Piercy, 1994; Lee, Ginn, \& Naylor, 2009; Morgan et al., 2007), leading to the creation of service networks. Service relationships are therefore becoming more complex through 
involving manifold actors, and this complexity can only be captured by employing a services network approach (Morgan et al., 2007; Tikkanen, Alajoutsijarvi, \& Tahtinen, 2000; Zolkiewski, Lewis, Yuan, \& Yuan, 2007). This is in line with the concept of "value creating systems", "value networks" and SDL (Lusch, Vargo, \& Tanniru, 2010; Normann \& Ramirez, 1993; Parolini, 1999; Vargo \& Lusch, 2004), according to which service "is created in a network of activities involving a host of stakeholders" (Gummesson, 2008, p. 16). The co-creation of value in service encounters involves therefore not only the process through which customers and suppliers engage in dialogue or interactive processes of joint learning (Ballantyne, 2004; Payne et al., 2008), but also the interplay with other actors throughout the network, including diverse service providers, facilitators, and third parties (Cova \& Salle, 2008; Vanhaverbeke \& Cloodt, 2006).

Regarding the processes of value co-creation, it is worth mentioning that while according to the SDL "value is always determined by the beneficiary of the service" (Vargo \& Lusch, 2008, p. 8), according to the IMP Group and the INA, value is "always determined by the beneficiary in terms of its relation to specific problems" (Ford, 2011, p. 233), with actors' subjective interpretation playing a key role in the assessment of the created value. Moreover, while the SDL recognizes that value is co-created between the supplier and the customer, it is the customer that assesses the nature and extent of the created value(-in-use) (Vargo \& Lusch, 2008). On the other hand, the IMP Group perspective of value is reciprocal by nature, given that actors' interactions reflect mechanisms to help them deal with particular problems (Ford, 2011); this extends the notion of value(-in-use) to include both participants.

The importance of the notion of a network relates to specific characteristics of such systemic entities, e.g. the interdependence between actors, such as providers, collaborators, and customers; indirect forms of collaboration; and actors' embeddedness in networks of relationships (Normann \& Ramirez, 1993; Spohrer et al., 2007; Syson \& Perks, 2004; Vargo \& Lusch, 2004). These conceptual developments are aligned with the growing interest by service researchers to develop studies in business-to-business environments (Briggs \& Griaffe, 2010; Doorn, 2008; Keiningham \& Perkins-Munn, 2003; Ryals \& Humphries, 2007): "[S]ervice management research today should re-orientate itself towards business-to-business services" (Vandaele \& Gemmel, 2007, p. 308). This call results from the considerable weight that inter-organizational systems have in the world's economy (Maglio \& Spohrer, 2008; Spohrer et al., 2007), as well as from the recognition that there are relevant differences between inter-organizational services compared with consumer services (Morgan et al., 2007). This means that findings from a business-to-consumer services context should not be uncritically generalized to business systems. We therefore conclude that although things are changing regarding the nature of research conducted in services research, there is still much work to be done.

\subsection{A definition of business service networks}

Services, and especially services networks, are contested concepts (Morgan \& Tax, 2004; Morgan et al., 2007). Therefore, in order to facilitate the discussion on business service networks, we derive the definition used for this study. After exploring previous research on business services networks, we discuss (narrow) definitions that can be found in the literature for this concept. Based on this discussion, we suggest a new definition for business services networks, which we integrate into our research.

While business service network research is still in its infancy, several definitions of service networks can be found in the extant literature. Morgan et al. (2007) argued that "by outsourcing or partnering with two or more firms to perform certain activities targeted towards customers, firms are engaging in [business] service networks" (p. 372). Business service networks are therefore associated with the notion of co-production of business service between service providers; it is about the co-delivery of a service within a business-to-business context, through which actors continually interact and access others' resources and technologies to cope with their own problems while consequently getting involved in the problem-coping processes of their counterparts (Ford, 2011). In this definition, two constituting elements have therefore to be present: all actors have direct contact with the customer, and each actor performs service activities that work together with other actors' service activities. This reflects a quite narrow view of business service networks (Morgan \& Tax, 2004), in line with defining a service network as "two or more entities connected formally or informally which directly provide a range of resources and activities that create value and help customers solve shortor long-term problems" (Morgan et al., 2007, p. 373). Such definitions of service networks focus only on provider services networks. Out approach to networks that is based on the business marketing and strategy literature (specifically the INA), allows for a more inclusive and broader definition of service networks. In this paper, we utilize such a broader view on service networks. Building on the INA, we define business service network as follows:

Business service networks are complex interdependent relationships between actors who are either traditional service providers (actors that hold an underlying services logic, such as hospitals, telecommunications, and consultancy firms) and that provide services to other firms, or that are traditional industrial companies which provide tailored solutions to their clients by integrating a service into the core product that they offer, in line with the notion of service infusion (Edvardsson et al., 2006).

It is therefore assumed that a business service network includes customers and both types of providing companies: traditional service providers and traditional industrial companies that are providers of customized infused offerings or solutions.

We are interested in investigating one particular aspect of business service networks: the process through which they emerge. Given the paucity of relevant research on this topic within a service network context, we draw on findings from other bodies of research that are closely related to this area to put forward some assumptions on how business service networks are formed. In the following section, we carry out a parsimonious review of previous research conducted on the process of emergence of business networks in general, as well as on the process of creation of clusters and innovation systems. Many of the findings from these specific areas of literature are relevant to business services networks and contribute to a better understanding of their formation.

\section{The emergence of business networks}

Despite the widespread recognition that inter-firm collaboration, competition and network embeddedness play a crucial role in firms' survival, growth, and performance (Flint, 1997; Ritter \& Gemunden, 2003; Walter, 2001), research on business network formation is rather under-developed (Dyer \& Nobeoka, 2000; Gulati, 1998; Gulati \& Gargiulo, 1999). The emergence and growth of business networks such as regional or national clusters are recognized as being of crucial importance from a theoretical perspective as well as from a policymaking standpoint (Rosiello \& Orsenigo, 2008). While a rich body of literature can be found regarding cluster formation, a specific form of (intentionally created) business networks or strategic nets (Gulati et al., 2000; Jarillo, 1988; Möller \& Svahn, 2003), only a limited number of studies cover more general issues of business network creation. Moreover, the existing studies on network formation are usually about orchestrated or 'top-down' networks, i.e., those where there is a focal firm that initiates the network formation (Dhanaraj \& Parkhe, 2006; Doz, Olk, \& Smith Ring, 2000; Dyer \& Nobeoka, 2000; Hite \& Hesterly, 2001). The study of 'bottom-up' or non-orchestrated networks 
(a form of exchange networks created as a result of collective action), has received scant attention (Brito, 2001; Roseira, Brito, \& Garrett, 2009).

\subsection{Business network formation}

There are three critical and interconnected areas that are central for understanding the process of emergence of business networks. These are as follows: the reasons business networks are formed or why actors have the need to interact with other actors, how network partners are chosen, and how environmental conditions affect the network formation process. These three aspects of business network formation are explored in this section by considering different theories within social sciences (Monge \& Contractor, 2003), namely exchange and dependency theory, homophily and proximity theory, and theories of network evolution.

\subsubsection{Reasons for business networks emergence}

Exchange and dependency theories build on information and resource allocation issues to explain the emergence of networks. Among these theories are social exchange theory (SET) (Blau, 1964; Emerson, 1962, 1972; Homans, 1950, 1974), resource dependency theory (RDT) (Pfeffer \& Salancik, 1978) and network exchange theory (NET) (Bienenstock \& Bonacich, 1992, 1997; Cook, 1977; Yamagishi, Gilmore, \& Cook, 1988). In summary, SET asserts that networks are built using a subjective cost-benefit comparison of available options; moreover, according to RDT actors interact to get access to the resources they need to develop their own activities; finally, NET identifies and analyzes structures or distributions of power. These theories are based on principles of exchange equality and mutuality: actors look for what they need in terms of information or material resources, at the same time having the ability to provide other actors with what these are looking for (Monge \& Contractor, 2003). There are nevertheless actors that hold more resources, or that are able to control crucial resources that others need; this generates situations of dependency, power imbalance, and inequality.

\subsubsection{Reasons for choosing specific network partners}

Homophily and proximity are two pivotal theories used to explain partner choice in business networks. Homophily theory (McPherson \& Smith-Lovin, 1987) is closely related to social comparison theory (Festinger, 1954) and similarity-attraction theory (Byrne, 1971; Heider, 1958), as well as self-categorization or social identity theories (Turner, 1987; Turner \& Oakes, 1989): actors choose others similar to them to reduce conflict in relationships and potential distress resulting from cognitive discrepancy. Such similarity facilitates communication, increases the possibility to foresee how the other party will behave, and nurtures trust (Brass, 1995). Similar personality characteristics (Brass, 1995; Tosi, 1992), involvement in similar activities or similar business foci (McPhee \& Corman, 2011) have also been used to explain the formation of networks via homophily partner choice. On the other hand, some authors claim that opposites attract, and partner choice thus results from heterophily mechanisms (Granovetter, 1973). Partner choice may also result from a combination between homophily and heterophily principles (Rogers, 2003).

As with homophily concepts, proximity theory is also grounded in the similarity doctrine, drawing on the principle that actors look for other actors who are similar from a location point of view (i.e., physically close) (Gorman, 1990; Johnson, 1992). Physical proximity increases the possibility for actors to meet and to interact, and therefore to assess and explore common interests (Homans, 1950). A non-linear association between physical proximity and the creation of communication ties has been posited, resulting from opportunities to better know each other by monitoring and learning about the other partner (Conrath, 1973; Homans, 1950).

Other theories that can explain the selection of partners can be found in the literature on network formation (Powell, White, Koput,
\& Owen-Smith, 2005), such as 'follow-the-trend' or the 'logic of appropriateness', according to which actors try to replicate the behavior representing the predominant choices in the network (DiMaggio \& Powell, 1983; White, 1981), or a preference for diversity and multiconnectivity (Powell et al., 2005). In this case, actors look for novelty, tending to interact with new and different communities, networking with diverse actors.

Gulati and Gargiulo (1999) added to this discussion on how partners are chosen. These authors argued that while network formation (or the reasons actors want to have ties with others) can be easily explained by exogenous interdependencies and factors such as the social structure of resource dependency (Pfeffer \& Salancik, 1978), the process through which partners are chosen is more difficult. It is not easy for actors to get access to information about potential partners' competences or needs (Van de Ven, 1976). As a result, actors base their decisions on information that they get through their existing or prior networks (Gulati \& Gargiulo, 1999). These authors found that "the probability of a new alliance between specific organization increases with their interdependence and also with their prior mutual alliance, common third parties, and joint centrality in the alliance network" (Gulati \& Gargiulo, 1999, p. 1439), reflecting the importance played by network embeddedness mechanisms.

\subsubsection{Environmental conditions and network formation processes}

Path-dependence, intentional management, and evolutionary theories are the most commonly used theories to explain how environmental circumstances shape business networks creation. According to Araújo and Harrison (2002), "path-dependence is best understood as a general framework to understand how temporal-relational contexts of actions are formed and how specific events can contribute to the reproduction or transformation of those contexts" (p. 6). Path dependence needs nevertheless to be differentiated from simple determinism. Furthermore, path dependence should also be understood in terms of past facilitating capabilities, e.g. path dependence can lead to technological growth resulting from the re-usage of existing knowledge (Araújo \& Harrison, 2002). Hite and Hesterly (2001) argue that path-dependence is the main factor behind the emergence of networks, while in more advanced stages, like the early-growth stage, networks become intentionally managed. While firms are initially highly dependent on their pre-existing social network (Birley, 1985; Larson \& Starr, 1993; Ostgaard \& Birley, 1994), these may limit firms' flexibility (Ahuja, 2000; Hite \& Hesterly, 2001). Therefore, as the network develops, it needs to be "managed or adapted" (Hite \& Hesterly, 2001, p. 282), with firms building on their reputation and increasing experience to get access to additional resources (Aldrich, Rosen, \& Woodward, 1987). Hite and Hesterly (2001) therefore claim that network management may imply a combination of path-dependence and intentional management.

Coming from a different stream of thought, the theories of network evolution and evolutionary and systemic approaches (Andersen \& Teubal, 1999; Avnimelech \& Teubal, 2004, 2008; Rosiello \& Orsenigo, 2008; Teubal \& Andersen, 2000) are based on actors characterized by bounded rationality who interact with other companies (Hodgson, 1993). According to Nelson (1995), there exists an evolutionary process underlying the changes that take place in the market and it is therefore crucial to understand the mechanisms that result in selection, variation and self-replication or reproduction of firms, or technologies. Drawing on this evolutionary view, the dynamics underlying the emergence of networks and their development process can be analyzed from various perspectives: using the social interaction that takes place, understanding the contextual circumstances and the processes that facilitate the emergence process, the dynamics of policy actions, etc. (Avnimelech \& Teubal, 2004).

Ruttan (1997) called for an integration of different models that can be used to explain network formations, claiming that none of the existing ones have the capacity to explain exclusively the issue at hand. We build on this same principle, arguing that the understanding of the process of emergence of networks would benefit 
from the combination of different theories related to environmental circumstances.

\subsection{Regional and national network formation}

Clusters constitute a specific type of network aimed at leveraging regional and national growth and development (Porter, 2000; Schmitz \& Nadvi, 1999). Considerable research has been conducted on aspects of cluster characteristics, namely in biotechnology, pharmaceuticals, and the high-tech sector. However, not much work exists on the process of cluster emergence and formation (Brenner, 2005; Rosiello \& Orsenigo, 2008).

\subsubsection{Antecedents of cluster formation}

Several distinct factors have been identified as playing a crucial role in the emergence of innovation systems and clusters. First, the role played by the anchor organization has been identified as central (Lucas, Sands, \& Wolfe, 2009). Anchor organizations for clusters can be large firms, public entities, public research institutions, etc. (Gertler \& Vinodrai, 2009), providing especially in-house capital and network connections. Anchor organizations are seen as "reservoirs of talent" (Lucas et al., 2009, p. 196). Secondly, the issue of building institutions has been discussed as playing a crucial role in a cluster's process of emergence (Perez-Aleman, 2005). Institutionalization plays an important facilitation role to coordinate learning processes between firms in order to develop competences and processes within the cluster (Perez-Aleman, 2005; Sabel, 1996). Such institutionalization can also contribute to forming a critical mass for the cluster (Perez-Aleman, 2005). Thirdly, talent concentration was another factor identified by both Lucas et al. (2009) and Gertler and Vinodrai (2009) as an important antecedent for cluster formation. This concentration results from the capacity that some organizations have to attract talented and skilled people, becoming 'magnet organizations' (Harrison, Cooper, \& Mason, 2004). Moreover, another important source for talent results from close collaborations between industry and universities; this also allows for successful processes of transferring knowledge to market. An intensification of research and teaching programs at local universities, and the training of highly qualified personnel (the result of joint training programs between research institutes, universities and industry), also contribute to talent creation and concentration (Lucas et al., 2009). A strong research infrastructure represents the fourth identified antecedent: Wolfe and Gertler (2006), as well as Lucas et al. (2009) claimed that the presence of public organizations in a specific region, namely a strong research university, is an important element in the creation of clusters. Research universities are an important source of innovation and create human capital. Differing from what Porter (1998) claimed, the public sector was found to contribute strongly to the emergence of clusters, by generating research conditions that lead to cluster emergence, thereby shaping emerging clusters (Bramwell \& Wolfe, 2008; Gertler \& Vinodrai, 2009). These findings are backed by a report produced by the OECD (2007). Public initiatives at the start-up stage, such as government programs that promote entrepreneurial endeavors, ground-breaking research or simply testing of the projects' feasibility, can trigger discussions between private firms, research institutions and public organizations, which may result in cluster creation (Perez-Aleman, 2000, 2005; Rosiello \& Orsenigo, 2008). Moreover, it is important for private and public initiatives to be coordinated and to complement each other, being able to build on existing, e.g. regional, strengths (OECD, 2007). Fifthly, entrepreneurial culture is believed to play a central role in cluster formation (Bresnahan, Gambardella, \& Saxenian, 2001; Feldman, Francis, \& Bercovitz, 2005). According to Lucas et al. (2009), cluster emergence relies on a strong research and knowledge base, through anchor firms, new start-ups or public sector institutions. This knowledge base reflects a "low opportunity cost of gaining access to ready supplies of skilled human capital" (Lucas et al., 2009, p. 193), and once it is established, entrepreneurship is triggered (Feldman et al., 2005; Rosiello \& Orsenigo, 2008).

\subsubsection{Process conditions and cluster formation}

The traditional cluster literature stresses the importance of geographical/local concentration for cluster development, as local firms are "embedded in thick networks of knowledge sharing, supported by close interactions and by (formal and informal) institutions that promote the development of trust among participants in the network" (Rosiello \& Orsenigo, 2008, p. 340). However, these proximity issues are not applicable to certain sectors, such as biotechnology. In this sector, knowledge spill-over effects rarely occur, as the main driver for these effects is not proximity but a company's absorptive capacity (Cohen \& Levinthal, 1990; Rosiello \& Orsenigo, 2008). Besides proximity and local concentration, the role of innovativeness in cluster formation is stressed in the literature, often with contradictory findings. Some authors claimed that cluster formation is closely associated with a region's level of innovativeness (Brenner, 2005; Camagni, 1995), while others posited that clusters are often formed in regions with low levels of innovativeness (Capecchi, 1992; Lorenzen, 1998). This points to the problem of identifying whether innovation is an antecedent or a consequence of local clusters (Brenner, 2005). Collaboration is a further factor, sometimes claimed as a cornerstone for a successful emergence of clusters (Brenner, 2005; Sengenberger \& Pyke, 1992; Vipraio, 1996). However, Staber (1996) asserted that empirical evidence does not support this statement. Brenner (2005) empirically observed that while cooperation with suppliers and universities played a crucial role in cluster emergence, the same could not be said about local cooperation among competitors.

\subsubsection{Environmental conditions and cluster formation}

Environmental conditions affecting cluster formation have usually been discussed in the context of path-dependency and evolutionary theories. Despite the recognition that some clusters grow through cumulative developments that result in "the concentration of a critical mass of private companies, skilled individuals, experienced intermediaries and the development of an adequate infrastructure to support $R E D D$ activities in a specific location" (Rosiello \& Orsenigo, 2008, p. 343), some authors argued that the clustering process and the special location of the cluster are purely accidental, resulting from 'historical accidents' (Krugman, 1991) or from stochastic processes of start-up and spin-off developments (Arthur, 1994). Other authors emphasized how cluster formation is determined by regionally distinctive features (Boschma \& Wenting, 2007), but that nevertheless there exists a 'coincidence' factor underlying cluster formation in those regions which exhibit certain necessary conditions. Nevertheless, most authors rejected such coincidences by arguing that it is fundamental to look into the causalities underlying these coincidences (Martin \& Sunley, 2006). Cluster formation is seen as path-dependent and locked-in (i.e. there are "thick institutional tissues aiming at preserving existing industrial structures") (Hassink, 2005, p. 522), which means that a region's route is determined by the pre-existence of a set of local factors, with triggering events leading to cluster formation (Gertler \& Vinodrai, 2009; Wolfe \& Gertler, 2006). Such path-dependencies can constitute an obstacle for cluster formation (Hassink, 2005): existing lock-ins that aim at protecting existing network configurations may hold back any form of re-organization and block new initiatives and innovations. Pathdependence therefore implies that there is not one single route for cluster formation; instead, there exist combinations of conditions, and several paths may result in thriving cluster formation processes (Lucas et al., 2009; Wolfe \& Gertler, 2006).

This issue of path dependence has also been empirically verified: Gertler and Vinodrai (2009) observed that cluster emergence is specific to each region, being associated with the activities carried out by diverse institutional and non-institutional actors, as well as with milieu conditions and chance events. Furthermore, Shapira and Yountie (2008) found empirical evidence which corroborates the work of Araújo and Harrison (2002) on path-dependence. However, while they found that path-dependence has an important role to 
play in determining the trajectory of cluster formation, actors also have strategic choices available and may use the extant structures as tools to achieve their own aims.

Besides path-dependencies, economic theory, namely the evolutionary and systemic approach (Andersen \& Teubal, 1999; Avnimelech \& Teubal, 2004, 2008; Rosiello \& Orsenigo, 2008; Teubal \& Andersen, 2000) has also been used to explain the impact of environmental conditions on cluster formation. Based on Saxenian's (1998) work regarding the development of Silicon Valley, Andersen and Teubal (1999) suggested that cluster reconfiguration occurs "where system of innovation transition proceeds from an existing to a new system of innovation" (p. 2); it is therefore associated with changes and adaptations that existing clusters go through as a consequence of new internal or external conditions. According to the idea of reconfiguration, the dynamics behind cluster formation are partly explained as part of the reconfigurations of a pre-existing system (Avnimelech \& Teubal, 2004).

\section{Conceptual framework}

Building on the literature review, we posit that the creation of service business networks such as the HCP reflects an iterative process of adaptations and reconfigurations. We therefore initially develop an analytical framework for analyzing such a process of network formation. The development of the framework was based on a process research approach (Langley, 1999; Mohr, 1982; Van de Ven \& Huber, 1990), according to which it is possible to understand how and why things change over time by identifying and analyzing the events, actions and choices that took place or were made over that period (Bidart, Longon, \& Mendez, 2012). In order to understand the sequence of events that lead to a specific result (like the creation of the HCP in its current form), we look for temporal ordering as well as probabilistic interfaces between different elements (Mohr, 1982), or patterns in events (Langley, 1999). However, and because process research takes into account the context in which the change is taking place (Pettigrew, 1992), a high level of complexity is expected, with parallel levels of analyses reflecting how researchers are "increasingly recognizing that the presence of multilayered and changing contexts, multidirectional causalities, and feedback loops often disturb steady progression towards equilibrium" (Langley, 1999, p. 694). Process research thus does qualify a more linear phase model, instead more complex process models are developed that consider deviations from the 'normal' route and the 'reuse' of different stages (Bidart et al., 2012). Our analytical framework reflects this fuzzier, less linear approach.
Our developed conceptual framework therefore aims at capturing two different aspects, which, once combined in a process model, allow us to understand the HCP creation process: first, what the business service network constellation looked like in each stage of development providing us with a comparative static or snap-shot perspective, and secondly, what events, actions and choices led to the evolution between stages, and how was this achieved, providing us with a dynamic perspective. The first element (comparative static analysis) was captured using the INA model to analyze business relationships and networks, while the second element (dynamic analysis) was informed by the different factors discussed in the social science literature and the literature on regional/national network formation, particularly path-dependency and general cluster theory. The two elements of the framework that result in our overarching process model are discussed further below.

4.1. Analytical framework for business service network analysis: Comparative static perspective

The so-called AAR model of the INA, suggested by Håkansson and Johanson (1992), is based on three variables: actors, activities and resources. This model has been used by business-to-business marketing researchers for an "integrated analysis of the stability and development of industrial systems" (Håkansson \& Snehota, 1995, p. 28): actor bonds are created between actors, who transfer or transform resources of diverse nature (resource ties) through activities (activity links). Actor bonds, activity links and resource ties "add up to a relationship" (Håkansson \& Snehota, 1995, p. 28). The three elements of the AAR model are closely interconnected (Ford, Gadde, Håkansson, \& Snehota, 2003), resulting in a network of different business relationships (Håkansson \& Johanson, 1992). Business interactions should therefore be analyzed as being embedded in a network of relationships, instead of being seen in an isolated way (Axelsson \& Easton, 1992). Based on these considerations, Håkansson and Snehota (1995) suggested a scheme of analysis of development effects of business relationships (see Fig. 1). This scheme relates the AAR model to three closely interconnected levels of analysis: company, relationship, and network. The development of a relationship between two actors implies the alignment of the three dimensions of the AAR model. There is therefore an interdependence between the organizational, the relational and the network levels of analysis; thus, there exists an interaction between 1) the perceived organizational structure, actor bonds, and the web of actors; 2 ) the perceived resource constellation, the resource ties, and the resource constellations; and 3) the

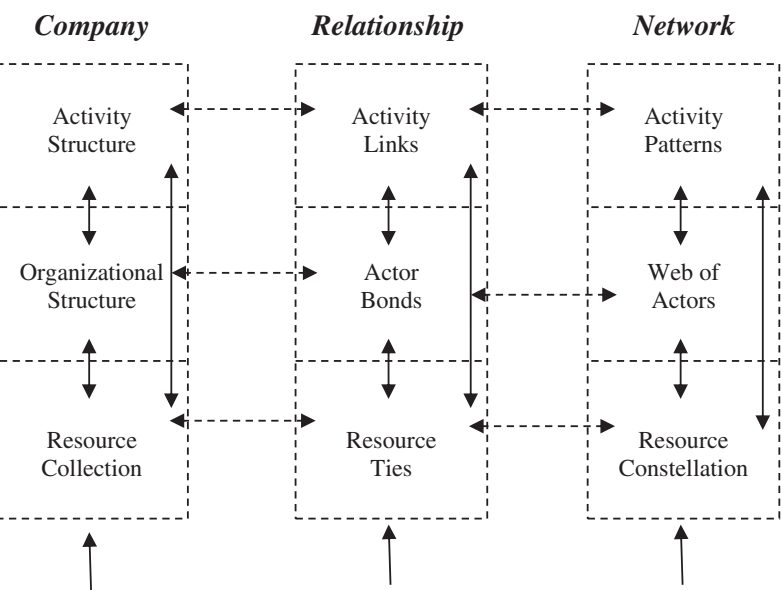

Critical Issues Capability development Marketing and Purchasing Strategy development

Fig. 1. Scheme of analysis of development effects of business relationships (adapted from Håkansson \& Snehota (1995)). 
perceived activity structure, the activity links, and the activity patterns.

As such, this framework provides a comprehensive way of understanding the static morphology of a business system, such as a service network. It therefore lends itself as an analytical tool for comparative static analyses of such networks by providing a deep structural understanding of different development phases. However, it does not provide a procedural view of such developments. To develop a comprehensive analytical model, such a process-oriented perspective needs to be added.

\subsection{Analytical framework for business service network analysis: Dynamic perspective}

Adding to the comprehensive snap-shot of a business network at different times of development, as provided by the AAR model, we also attempt to portray what is taking place between each stage of development of the business service network (Bidart et al., 2012), by identifying the main iterative processes reflected in terms of events, actions, and choices (Langley, 1999), which contribute to a change of the structure of the network (see Fig. 2). For this purpose, we use the theories from social sciences which identified a repository of important aspects that contribute to the understanding of the formation of business networks, namely different theories of network formation (i.e., NET, RDT, and SET), criteria of choice of network partners (homophily, heterophily, proximity, embeddedness mechanisms, diversity, and appropriateness), and finally environmental conditions (path-dependence, intentional management, and evolutionary theory). This also includes the specific theories on cluster formation (namely, antecedents and process conditions, such as the role played by anchor organizations, building institutions, talent concentration, research infrastructure, entrepreneurial organizations, proximity and geographical distance, level of innovativeness, and the level of collaboration), in order to sensitize the analysis to ways of understanding the transition between different stages in the business service network creation.

We therefore propose the integrated analytical framework presented in Fig. 2 as a tool that facilitates an understanding of both process as well as structural aspects of the emergence of business service networks. The framework results from an adaptation of Langley's (1999) and Mohr's (1982) work on process research, and satisfies the criteria of Bidart et al. (2012) for time and process research.
The framework that we put forward shows that we do not expect to find a clear distinction between the different stages of development of a business service network: the development process reflects a continuum of events, actions, and choices that are closely intertwined, where results interact with each other in a constant shaping and reshaping of the resulting outcomes as well as the context (Langley, 1999; Pettigrew, 1992). One may therefore expect development stages to take place not in a sequential order but to a certain extent in parallel (Bidart et al., 2012), and to be conditioned partly by the same events, actions, and choices, although resulting in diverse outcomes.

\section{Methodology}

This paper presents an initial exploratory case study of a specific business network in the services sector: the Health Cluster Portugal (HCP). Case studies have been found to be particularly useful to carry out research in business-to-business marketing (Woodside \& Wilson, 2003), and more specifically in business networks (Easton, 1995; Halinen \& Törnroos, 2005). Our goal is to analyze the process of emergence of the HCP, which is aimed at fostering the creation of a national competitive and technological cluster that draws on the extant competences and potential of the medical sector in Portugal; promoting the economic and social development of the involved regions, as well as of Portugal as a whole; increasing exports; and finally, contributing to the improvement of the health care system and services. Our case therefore constitutes a services network aimed at "improving well-being through transformative service" (Ostrom et al., 2010, p. 6). Services focusing on the improvement of wellbeing constitute a research priority that requires further investigation (Ostrom et al., 2010), which motivated the selection of this particular case for analysis.

As mentioned in the conceptual framework section, this study is based on process research (Mohr, 1982), given that its focus relies in "understanding how things evolve over time and why they evolve in this way" (Langley, 1999, p. 692). Our research provides a retrospective description and analysis of the HCP emergence process, since its inception in 2005 until the end of 2010 . We take 2005 as the starting point based on the data analysis; 2010 was used as a final date as this marks the beginning of the implementation of specific sub-projects as part of HCP. These implementation activities are considered as the

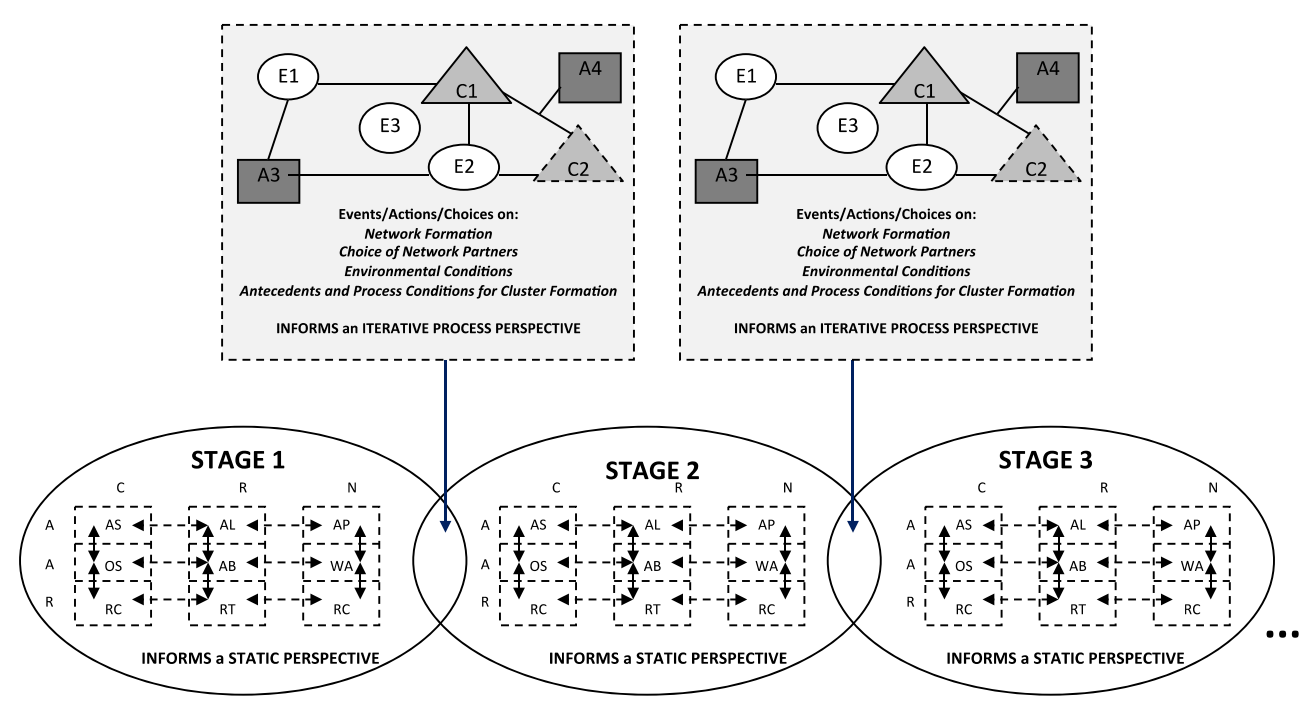

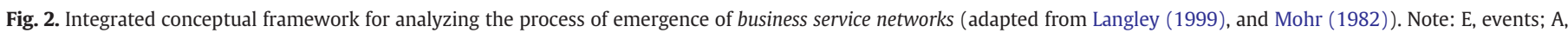
actions; $\mathrm{C}$, choices. The depictions in the stage bubbles refer back to the model introduced in Fig. 1. 
end of the emergence stage of this particular business service network as it represents a consolidation within the cluster with actual formal activities binding actors and their resources together. Furthermore, these activities are also perceived as a 'point of no return' for the cluster by its participants.

Data collection took place during six months in 2010. The initial analysis of secondary data (mainly press coverage and official reports), and exploratory interviews with the president and the executive director of HCP, led us to confirm that the case was adequate for our research. These first exploratory interviews were also used to confirm HCP's willingness to collaborate with the research team, namely to identify and facilitate access to the relevant organizations and informants. In the main data collection phase, all identified organizations and individuals who were associated with the HCP's emergence process were interviewed. We used multiple semi-structured interviews with nineteen individuals, as illustrated in Table 1 . The interviews, which were taped and transcribed, were normally between 1 and 2 hours long, and were conducted in the mother tongue of those interviewed.

The interviewees belonged to institutions of different types: two political/administrative bodies (CCDR-North and COMPETE), six research centers (IPATIMUP - Institute of Molecular Pathology and Immunology at the Universidade do Porto, IBMC - Institute for Molecular and Cell Biology of Porto, INL - International Iberian Nanotechnology Laboratory, INEB - Institute for Biomedical Engineering, CNC - Centre for Neuroscience and Cell Biology, and IMM - Institute

Table 1

Participation of interviewees in the process of emergence of HCP.

\begin{tabular}{|c|c|c|c|c|}
\hline Interviewees & $\begin{array}{l}\text { Stage } \\
0-1\end{array}$ & $\begin{array}{l}\text { Stage } \\
1-2\end{array}$ & $\begin{array}{l}\text { Stage } \\
2-3\end{array}$ & $\begin{array}{l}\text { Stage } \\
3-4\end{array}$ \\
\hline \multicolumn{5}{|l|}{ CCDR-N } \\
\hline President & Involved & Involved & Involved & Involved \\
\hline $\begin{array}{l}\text { Vice-president (and Professor at } \\
\text { Universidade do Minho) }\end{array}$ & Involved & & & \\
\hline Vice-president & Involved & Involved & Involved & Involved \\
\hline \multicolumn{5}{|l|}{ COMPETE } \\
\hline $\begin{array}{l}\text { Coordinator of the collective efficiency } \\
\text { strategies }\end{array}$ & & & Involved & Involved \\
\hline Executive secretary & & & Involved & Involved \\
\hline \multicolumn{5}{|l|}{ IPATIMUP } \\
\hline $\begin{array}{l}\text { President (also a Professor at } \\
\text { Universidade do Porto and head of } \\
\text { service at Hospital de S. João-the } \\
\text { 2nd largest public hospital in } \\
\text { Portugal) }\end{array}$ & Involved & Involved & Involved & Involved \\
\hline IBMC & Involved & Involved & Involved & Involved \\
\hline $\begin{array}{l}\text { Former director (also Professor } \\
\text { at Universidade do Porto) }\end{array}$ & Involved & Involved & Involved & Involved \\
\hline $\begin{array}{l}\text { Current director (also Professor } \\
\text { at Universidade do Porto) }\end{array}$ & & & & Involved \\
\hline INL (operations manager) & & & & Involved \\
\hline $\begin{array}{l}\text { INEB: scientific coordinator } \\
\text { (also Professor at Universidade } \\
\text { do Porto) }\end{array}$ & & Involved & Involved & Involved \\
\hline \multicolumn{5}{|l|}{$\mathrm{CNC}$} \\
\hline $\begin{array}{l}\text { President (also Professor at } \\
\text { Universidade do Coimbra) }\end{array}$ & & & Involved & Involved \\
\hline \multicolumn{5}{|l|}{ IMM } \\
\hline $\begin{array}{l}\text { President (also Professor at } \\
\text { Universidade do Lisbon and head } \\
\text { of service of Hospital de Santa } \\
\text { Maria-the largest } \\
\text { public hospital in Portugal) }\end{array}$ & & & Involved & Involved \\
\hline $\begin{array}{l}\text { HOVIONE (vice-president) } \\
\text { BIAL }\end{array}$ & & & Involved & Involved \\
\hline CEO and currently President of HCP & Involved & Involved & Involved & Involved \\
\hline EUROTRIALS (CEO) & & & & Involved \\
\hline BIOCANT (scientific director) & & & & Involved \\
\hline HCP & & & & Involved \\
\hline $\begin{array}{l}\text { Executive director and formerly owner } \\
\text { of a medical device manufacturer }\end{array}$ & Involved & Involved & Involved & Involved \\
\hline Two project managers & & & & Involved \\
\hline
\end{tabular}

for Molecular Medicine), three pharmaceutics-related companies (Bial, Hovione, and Eurotrials), one Bioscience Park (Biocant), and the HCP management body. With the exception of COMPETE's executive secretary and the two project managers of HCP (hired after the cluster's formal creation), all other interviewees were directly involved in processes even before the formal emergence of the cluster. They hold (or held) top positions in the institutions that they represent. Several interviewees are associated with different institutions simultaneously (in Table 1, their major organizational links are indicated in capital letters, while their roles in other institutions are mentioned in brackets). The diversity of roles played by some interviewees made them particularly knowledgeable of the different problems, strengths, interests, and points of views of different institutions in the health sector in Portugal during the HCP emergence. Thus, the interviewing process provided us with a deep understanding of the issues at hand by capturing possible contrasting views, different interests at stake, as well as varied perceptions and meanings (Dubois \& Araújo, 2007; Jårvensivu \& Törnroos, 2010). This resulted in a "polyphonic" narrative of the case (Lowe \& Hwang, 2012, p. 707). Additionally, interviewing all the actors that were directly involved in the HCP creation revealed the richness and complexity of the case, also limiting the risk of getting an incomplete and biased view (Gummesson, 2003; Huber \& Power, 1985). Given the retrospective nature of this investigation, such triangulations were especially important (Huber \& Power, 1985).

The interviewing process was ended when all relevant actors had been identified and interviewed, i.e. when the informants were no longer able to indicate the participation of additional actors in the process of emergence. Other sources (reports, press cuttings, website information, and internal HCP documents) were also used to collect, complement and triangulate data and ensure validity (Dubois \& Gilbert, 2010). The combined use of primary and secondary data was also essential for widening and deepening the researchers' understanding of the case (Yin, 1994) and of the subject (Ritchie \& Lewis, 2003). Additionally, the research covers a rather long period (5 years) of HCP's emergence process, and we were interested not only in identifying events, but also in capturing the significance and connotative meaning that the involved actors attributed to each event (Lowe \& Hwang, 2012). As such, the combination of historical and synthetic data (e.g., press articles published during that period) and retrospective interviews allowed us to identify critical discrete events, as well as the contextual factors that affected those events, and finally the involved actors' interpretations of, and reactions to, the events mentioned (Langley, 1999).

The data resulting from the transcribed interviews and other data sources were analyzed using NVivo. To capture the structural as well as process-oriented aspect of the HCP emergence, the goal was, first of all, to identify the cluster's underlying stages of creation and development. We also aimed to identify themes related to the context, process, and outcomes of the creation process, as well as the shared beliefs about, for example, environmental factors inducing cooperation. Additionally, we wanted to understand actors' common interests, existing resources and activities, and how these could be activated in a business service network. Finally, we looked for aspects related to the actors' geographic and activity scope, criteria used for partner selection, ascriptions about what the cluster should be about, the centrality of actors (individuals and institutions), and also the roles they should assume in the creation process and in the management of HCP. The case analysis was thus mainly guided by the analytical framework, providing an evidence trail that contributes to the study's internal validity (Gibbert, Ruigrok, \& Wicki, 2008) and credibility (Fereday \& Muir-Cochrane, 2006). The description of the HCP cluster development stages (Section 6.1) and the characterization of HCP cluster emergence processes (Section 6.2) resulted from the interacting narratives provided by the interviewees (or first order narratives), interpreted and consolidated through the use of the analytical framework in a second order narrative, or a 'narrative of narratives' (Lowe \& Hwang, 2012).

In order to increase validity and consistency, interviews were independently content-analyzed by two researchers in order to identify 
divergences in interpretation and coding (Krippendorff, 2004; Miles \& Huberman, 1994); after discussions, no relevant divergences were found. In a second validation step, the resulting case narrative (summarized in the next section) based on the collected data was sent to the HCP's executive director and the main project managers for confirmation. This process resulted in some minor adjustments to the narrative, improving its accuracy (Gibbert et al., 2008).

Thus, we have combined in our analysis design three out of the seven alternative strategies put forward by Langley (1999) to analyze process data: narrative, temporal bracketing, and alternate templates. First, we used a narrative strategy to provide a thick description of the case (Lincoln \& Guba, 1985) and to clarify the importance of contextual factors (Pettigrew, 1997). Second, the temporal bracketing strategy was used to structure the description of events, resulting in the identification of five different stages of the HCP emergence process. The application of a stable analysis tool like the AAR model to each stage revealed important disparities between the different stages. The AAR model's different configurations in each stage seemed, however, insufficient to fully explain the discontinuities identified between the stages. For this reason, the final alternate template strategy draws on the fields of cluster theory and of social sciences theory, and was critical to fully understand and explain those discontinuities. According to Langley (1999), each of these strategies requires one or more cases to theorize from process data: on case for an alternate templates strategy, one or two cases for a temporal bracketing strategy, and finally one or few cases for a narrative strategy. We believe that the richness of the chosen single case, together with the combination of those three theorizing strategies allowed us to provide a "theoretical understanding that does not betray the richness, dynamism, and complexity of the data but that is understandable and potentially useful to others" (Langley, 1999, p. 694).

\section{Case analysis: The process of emergence of the HCP}

The analysis of the data, including the interviews and the additional documentations, resulted in the identification of five main stages underlying the creation of the HCP. Each stage involves different and sometimes overlapping actors and aims, as well as different actor bonds, resource ties, and activity links. Different innovation processes and outcomes can also be associated with each of the identified stages. In this section, we begin by describing each of the stages that were identified for the HCP creation. We then use the frameworks to analyze the process of emergence of business service networks in order to understand what was occurring structurally in the network at each stage, and what the factors were that explain the transition and development between stages.

\subsection{HCP cluster development stages}

\subsubsection{Stage 0 (2005-2006): NORTH 2015}

The process that led to the creation of the HCP in April 2008 can be traced back to 2005: CCDR-North, with the aim of preparing and defining a strategy for the development of Northern region of Portugal, launched an initiative known as NORTH 2015. CCDR-North is a public institution and part of the Portuguese Ministry of Environment and Territory that promotes regional development. The aim of the initiative was to identify, through intensive interactions via meetings and workshops with public and private organizations of the region, areas or sectors with potential for fostering the economic development of the north of Portugal. The final purpose of this exercise of prospective diagnosis was to define a strategy on how to allocate European funds that would be made available via QREN (the National Strategic Reference Framework), a forthcoming European financial development program. The approach was bottom-up, i.e. the project relied a lot on the initiative and mutual knowledge between politicaladministrative institutions, universities, companies and other actors.
The outcome of this exercise led to the identification of health sciences as a priority area, a sector that reflected a strong potential for increasing the competitive performance of the region, adding value, creating new jobs, providing access to international markets, and thus fostering the region's economic development. Several reasons led to the identification of health sciences as the main opportunity for the northern region of Portugal. First, the north is home to a considerable number of renowned organizations in the health area, especially with research credibility: IPATIMUP, IBMC, and INEB, Universidade do Porto, Universidade do Minho, as well as BIAL. Thus, the region was already characterized by a nascent network of connections and knowledge of the sector. For example, there were strong relationships between three research entities - IPATIMUP, IBMC and INEB - and the pharmaceutical company BIAL, as well as with local hospitals and smaller companies; hospitals were even members of INEB, participating in research projects. Due to their reputation, these provided credibility and critical mass. Additionally, there existed a highly qualified and significant critical mass in health-related areas, such as ICT, bioengineering, biotechnology, food engineering, consumer health and safety. It is in the northern region of Portugal that the national R\&D in the health and life sector is concentrated, namely around the Universidade do Porto and Universidade do Minho. Several indicators, such as the number of bachelor's degrees and PhDs in relevant topics, or the number of scientific publications in the health area, point to the strong potential of the region in the health sector area, namely with regards to knowledge creation and research activity.

At this stage of NORTH 2015, the idea was not to actually do something with the findings; instead, it was about creating a sense of involvement and common awareness of the potential for developing the health sector in the north. This way, when the time came to implement a plan that would allow investing in the health sector, the idea would already have been through a gestation process, with a common 'network insight' forming (Mouzas, Henneberg, \& Naudé, 2008). Moreover, the findings disseminated and reinforced the belief that there were clear advantages in companies and research institutes working together in the health sector, thus exchanging ideas and information, and knowing each other to mobilize potential resources within a business network.

\subsubsection{Stage 1 (2006-beginning 2007): GDMF (Medical Device and Pharmaceutical Group)}

CCDR-North had the capacity to identify key actors and get them involved in the NORTH 2015 exercise for prospective economic development. These key actors, which were either directly involved with the health sector (e.g., the president of a pharmaceutical company, and the manager of a medical devices company), or with the production of knowledge that could be applied to health (e.g., researchers at universities), decided to move things forward and to work with CCDR-North to create a regional health cluster in Portugal: the Medical Device and Pharmaceutical Group (GDMF). It is common for people to talk about the 'holy alliance' that took place at this time. This first cluster is said to have been successful mostly as a result of the 'special' people and companies/organizations involved. While the project did not have governmental financial support, it was put together relatively fast.

The idea of creating a regional cluster for medical devices and the pharmaceutical industry resulted from the combination of several factors. To begin with, these specific industries presented a strong potential for development in the region, as identified in NORTH 2015: the region hosted the country's most dynamic organizations involved in the medical devices and pharmaceutical sectors. Moreover, besides being home to a vast number of companies associated with more traditional manufacturing industries like textiles and electro-mechanics, new knowledge-intensive activities were gradually emerging in the north, linked to universities, laboratories, hospitals, and health-related centers. There was an interesting potential interface between traditional 
industries and more high-tech ones, which could be fostered with the creation of the cluster. The cluster therefore addressed a social need for this specific region of the north of Portugal by promoting and intensifying the already existing innovative use of the extant resources of traditional industries. GDMF reflected an opportunity to use the capabilities and resources that already existed in the region in a new and innovative way: using the skills of highly qualified workers from more traditional industries, integrating their work with high-tech oriented industries to create products like new types of clothing material applied to the health sector. These projects were very appealing to the Universidade do Minho (namely to the Faculty of Engineering), given that medical devices were perceived to be a good way for fostering relationships between the faculty and industry.

GDMF is considered by many (including by the HCP's current president) as the first formalization of a nascent health cluster in Portugal. It formed a formal platform bringing together entities from the national scientific and technological networks (universities, research institutes and R\&D centers), as well as companies from the medical devices and pharmaceutics sectors, companies that supplied complementary resources (e.g., ICT consultants), and other members (a technology park, CCDR-North, and two GPs). About 25 organizational and individual members formed this cluster, which aimed at achieving a competitive national and international position in terms of research, innovation, and development of medical devices and pharmaceutical services.

The group was solely based on a confidentiality agreement and it did not meet very often. However, GDMF set as a target the implementation of several projects that would imply the creation or strengthening of activity links between different actors. For example, the Mobile Health Living Lab would involve the following partners: patients, mobile operators, GDMF, hospitals, universities, and others. New resources, such as medical devices to support patients' mobility, were meant to be created, actors would interact to monitor patients considered high risk, and communications between health units and patients would be improved and strengthened. However, the only tangible outcome from this stage was a directional wheelchair product that by 2010 had still not reached the market. Nevertheless, the group achieved several other aims that were crucial for the subsequent development of the HCP creation process. For example, members collected information with the aim of mapping the technological potential of the region, and they invested joint efforts into understanding what was being done outside the cluster. Therefore, arguably the most significant output of this phase was not tangible, instead, it was the new interactions and activity linkages that were created as well as an improved actor and resource awareness by a substantial number of what would become key players in the HCP. This information transparency did not exist before this stage; especially the information gap between research institutions and companies had been substantial. There were nevertheless some exceptions: some companies already had a vast knowledge of what was going on in the sector.

\subsubsection{Stage 2 (beginning of 2007-beginning 2008): Group of Sciences of} the North

The next stage was initiated due to a perception among GDMF's members that the initial health cluster in the north of Portugal, which only included medical devices and pharmaceutical products, was excluding a very dynamic and important area of the health sciences from that region: the bio area. Consequently, GDMF acted as a group and mobilized new members to join: three research institutes (IPATIMUP, INEB and IBMC) that were at the same time working towards their fusion into a mega-research institute known as I3S (the Institute for Health Innovation and Research). The newly formed group, known as the Group of Sciences of the North, formed with the support of CCDR-North. As a result, complementary resources were integrated into the emerging network.

\subsubsection{Stage 3 (beginning 2008-April 2008): HCP Founding Group}

After meeting two or three times, the members of the Group of Sciences of the North came to the conclusion that, although the group's dimension (in terms of actors, activities, and resources) was already developing, it was not sufficient as the scope was regional; thus, they had to get other national entities to join their working group. Only then could a health cluster services network be competitive on an international scale. This was the stage where the decision was made to instigate activities to expand the regional and northern health cluster into a national cluster. The high potential northern region would nevertheless still be recognized as the center of gravity in any national cluster.

The two actors who were most identified with the previous efforts met with three key players from Lisbon and Coimbra that were considered the research institutions in Portugal with the highest quality of knowledge production in the health area. The meeting, while merely aimed at generally discussing a national cluster project, resulted in these three institutions immediately joining the group. This was mainly attributed to the fact that the representatives of all involved parties, although their organizations may not have worked together before, knew each other well and there existed an openly stated mutual respect. This meant that ten entities were now involved in what was known as the Founding Group: the pharmaceutical company BIAL, the research institutes IPATIMUP, IBMC and INEB that form the I3S, INL, the Universidade of Minho and Universidade of Porto, CNC, IMM, Hovione, and CCRN-North. This group combined different entities (universities, research institutes, pharmaceutical companies, and medical device companies) from different parts of the country, thus covering large parts of the health sector.

The Founding Group met several times and discussed structural aspects such as who should be included in the national cluster, how each organization should contribute to the whole network, and what the cluster's main areas for strategic action should be: promoting promoting well-being/quality ageing, e-health, and the fight of specific diseases: cancer, neurodegenerative, cardio and osteoarticulation degenerative diseases. The main idea was to get a strategy, governance structures, and processes in place for a national health cluster, which would then be open to everyone interested in joining, and that could add important resources to the cluster. The cluster was not intended to be a 'by invitation-only' club instead, it was envisaged to be open to everyone that had the potential to become a valuable member.

Drawing on their personal knowledge of the health sector and on a preliminary scanning of the aspirations and capabilities of all actors in the Portuguese health sector, the founding group was able to identify an action plan, as well as the cluster's areas of strategic focus. The cluster was to have a national dimension, covering the whole (health) services network, taking advantage of the high quality scientific knowledge that was being produced in Portugal, and trying to speed up commercialization (barriers to transferring any produced knowledge into marketable offerings was one of Portugal's main weaknesses in the health sector). The aim was therefore to get the whole health network represented in the cluster: from science and knowledge creation, manufacturing and services companies, passing through hospitals and GPs, and finishing with the patients. The Founding Group began using their connections as well as word-of-mouth, talking with hospitals, research institutions, etc., in order to get the most important organizations mobilized to join a more national cluster.

With the support of CCDR-North, the group visited successful health clusters in Europe. The Danish-Swedish life science cluster Medicon Valley was selected as the most interesting target due to commonalities with the Portuguese health services sector. Benchmarking Medicon Valley's model, the group worked towards the idea of creating a non-profit and fee-based member organization (i.e. a governance structure), something that corresponded to the Medicon Valley Alliance. This had a 'light-touch' management team whose remit was to facilitate the 
cluster's functioning, promoting joint initiatives between its members. The role of this created entity would not be that of doing; instead, it was that of mobilizing actors so that things would get done. For example, IPATIMUP realized through the HCP management team that it could apply for European funding to develop translational research. With the help of Medicon Valley's president, who acted as an informal consultant for the Portuguese national cluster, the legal guidelines for the future HCP were developed in the beginning of 2008.

Almost in parallel with the Founding Group and the creation of the principles underpinning HCP, in January 2008, with the support of CCDR-North, the fusion between IPATIMUP, IBMC and INEB was formalized, resulting in the creation of I3S: a new scientific super-structure with great potential for growth. This physical sub-cluster was created following the logic of economies of scale and scope that emerged from a joint awareness that there was a need to unite forces and share resources. Although the creation of this group has been completely independent from the creation of HCP, it played a crucial role in the latter's emergence, as well as in mobilizing additional members. This was the first time in Portugal that three research institutes, without upfront governmental funding, decided to merge to increase their scale (in the research area, the trend was more towards fragmentation). The merger generated widespread trust among potential members, illustrating that it was possible for entities that would normally be competing for funding to work together. Finally, the merger also provided an innovative way of looking at health-related issues, by integrating genetics into the sector, and by using highly developed research techniques to understand causes of diseases. With its underlying strong scientific as well as technological, economic and productive potential, the creation of I3S considerably enriched the situation just before the HCP formally came into existence.

\subsubsection{Stage 4 (April 2008-present): HCP (Health Cluster Portugal)}

In April 2008 the HCP was formally constituted, through a bottomup process, as the result of a voluntary cooperation agreement between its members. At the time of its constitution, the founders expected to have around 20-25 members. Instead, there was a constant influx of members, with members immediately signing up. The founding members believe that this was the consequence of the reputation and credibility of the people and entities involved in the previous stages preceding the formation of HCP. Moreover, organizations liked the fact that at this point, the recognized regional north versus south rivalries (specifically Lisbon versus Porto) - an important national political and social issue - had already been overcome in the preceding stages. By the end of 2008, there were already 84 members in the HCP.

Besides the support given by CCDR-North (institutional support which was reflected in motivation as well as resources for the initial HCP facilities), there were no incentives by authorities for the foundation as a national health cluster. The governmental policy and legislation that promoted the creation of national clusters of competitiveness only came into existence after the HCP was formally created. The cluster's aims were aligned with this legislation on national clusters, and thus the HCP immediately submitted an application to be recognized as a national cluster for competitiveness, drawing on a strategy of collective efficiency. The motivation was to be more ambitious in its aims, while not changing its main objectives; the HCP had its own strategy and a program for viability that always went beyond any of the governmental programs. The government organization that was responsible for defining the priorities for each national cluster, questioned the HCP about areas for potential development. There was, therefore, joint work done by these two entities (government and HCP) that resulted in the definition of the priorities for the national health cluster for future years. The cluster thus quickly gained importance on a national level, by participating and strongly influencing the future areas of investment in the overall health sector.

In October 2009 a strategic plan was formalized for the HCP and its members, with the definition of long-term goals (10 years). Although there were already relationships between some of HCP's members, what HCP allowed was some time for the initial creation of a platform for dialogue and a meeting place between its members, in order to foster the generation of common aims for activities. Most members emphasized the importance of these initial meetings and workshops promoted by the HCP for informal networking. This led to clearly defined HCP-related sets of projects: flagship horizontal projects, and sub-projects that resembled sub-clusters within HCP. The horizontal flagship projects were created and managed by the cluster management itself. However, HCP's plan is to step back once the conditions have been created for the autonomous functioning of these projects. Sub-projects or complementary projects are created and managed by groups formed from the member institutions, and are aligned with the cluster's strategic guidelines.

Currently (April 2011), HCP has around 100 members, and its headquarters are located in the North (near Porto). HCP is now merely a facilitator and it is still working on the creation of platforms for dialogue and interactions. There is a shared belief that when the projects take hold within the HCP, there will be a natural selection of which organizations will stay or leave the cluster. A learning process is still taking place among the HCP members, in the sense that they are working towards adopting a transversal vision (across different layers of actors in the health service) that will allow integrating health and economic issues. Although the HCP has grown very quickly, with a sudden increase of entities joining the cluster, some partners are still trying to understand what the cluster is all about. While there were some organizations and personalities that played a crucial role as motivator in the formation of the HCP, these have now slightly stepped back; some of the projects became more autonomous and gained their own dynamics. However, the predominant feeling among the Founding Group is that there is now a greater level of intensity of contacts and interactions between a variety of hitherto unconnected organizations in the health network, which resulted in targeted projects being created or collaboration strategies being carried out.

The morphological characteristics of the five identified stages are summarized in Table 2 (i.e., a comparative static analysis between the identified stages).

\subsection{HCP cluster emergence processes}

Now that each identified stage underlying the process of creation of the HCP has been described, we apply the suggested framework of analysis. This framework characterizes this business service network at each stage of its emergence (see Table 2), and then provides an understanding of the mechanisms through which the process of emergence took place, which constitute the driving forces behind the transitions between the identified stages (Table 3 ).

The processes related to the development from stage 0 to stage 1 , i.e., the formation of the Medical Device and Pharmaceutical Group GDMF, were driven by the recognition of the importance of the health area for the north of Portugal, with strong network ties already established between different relevant and geographically close actor groups (e.g., universities, research institutions, and medical device companies), and an entrepreneurial tradition. At this stage, cluster members were selected based on homophily, given that entities engaged in similar activities, and with similar resources were preferred. However, these selection choices were conditioned by previously existing alliances, collaborations, and business relationships of the actors involved. Certain actors can be characterized as 'anchors' for the cluster development, with the institution being especially driven by CCDR-North and BIAL, which also serve as "magnet organizations' for talent concentration. As such, a certain path-dependence of the transitional development existed, especially regarding the issue of cluster membership; however, the strategic aims of the cluster were intentionally defined. The stage $0-1$ transition can be explained 
Table 2

The characteristics of the HCP at each stage of the process of emergence - a comparative static perspective.

\begin{tabular}{|c|c|c|c|}
\hline \multicolumn{4}{|c|}{ Stage 0 (2005-2006): NORTH 2005} \\
\hline & Company & Relationship & Network \\
\hline Activities & $\begin{array}{l}\text { Development of in-house R\&D activities by uni- } \\
\text { versities, R\&D institutes and companies in the } \\
\text { medical devices and pharmaceutical industries. }\end{array}$ & $\begin{array}{l}\text { - Universities developing research activities with } \\
\text { companies from the medical devices sector. } \\
\text { - R\&D institutes working with BIAL (pharmaceutical } \\
\text { company) to develop new medicines. } \\
\text { - Interface between companies from traditional sec- } \\
\text { tors and more high-tech ones. } \\
\text { - Activity links between universities and companies } \\
\text { operating in the medical devices sector. }\end{array}$ & $\begin{array}{l}\text { - Concentration of R\&D activities, namely around two } \\
\text { universities (Universidade do Porto and Universidade } \\
\text { do Minho). } \\
\text { - No significant tradition of transforming the knowl- } \\
\text { edge produced in universities/R\&D centers into com- } \\
\text { mercial goods. } \\
\text { - Strong activity linkage between universities, compa- } \\
\text { nies from more traditional sectors and companies } \\
\text { from the medical devices sector. }\end{array}$ \\
\hline Actors & $\begin{array}{l}\text { - Strong concentration in the north of Portugal of re- } \\
\text { nowned agents or opinion leaders in the health area. } \\
\text { - Strong concentration of companies from more tra- } \\
\text { ditional sectors (e.g., textile, electro-mechanic). } \\
\text { - Location of the country's most dynamic set of enti- } \\
\text { ties operating in the medical devices and pharma- } \\
\text { ceutical sectors. }\end{array}$ & $\begin{array}{l}\text { BIAL, IPATIMUP, INEB, IBMC, Universidade do } \\
\text { Porto and Universidade do Minho, have long-term } \\
\text { established connections with national and inter- } \\
\text { national entities associated with the health value } \\
\text { network. }\end{array}$ & $\begin{array}{l}\text { - Strong inter-linkage and closeness between the } \\
\text { most relevant actors of the north. } \\
\text { - Researchers from Universities and R\&D institutes } \\
\text { have the tradition of working in a network logic. } \\
\text { - Intensification of contacts between relevant actors } \\
\text { from the health sector, result of CCDR-N's efforts, } \\
\text { by promoting workshops and discussion sessions. }\end{array}$ \\
\hline
\end{tabular}

Resources • High volume and quality of scientific knowledge • Development/creation of medical devices.

produced in Universities and R\&D institutes.

- Credibility and critical mass of some actors (BIAL, IPATIMUP, INEB, IBMC, Universidade do Porto and Universidade do Minho).

- Highly qualified artisans (labor force) from more traditional industries.

- Highly technological oriented industries/institutions.

- Highly qualified and significant critical mass in several health related areas (technology, biotech, biologic engineering, biotechnology, food engineering, consumer health and safety).

Stage 1 (2006-beginning 2007): GDMF (Medical Device and Pharmaceutical Group)

\begin{tabular}{|c|c|c|c|}
\hline & Company & Relationship & Network \\
\hline Activities & & & $\begin{array}{l}\text { - Intensification of activity linkage between univer- } \\
\text { sities, companies from more traditional sectors and } \\
\text { companies from the medical devices sector. }\end{array}$ \\
\hline Actors & & & $\begin{array}{l}\text { - Stronger interaction between the actors operating } \\
\text { in the medical devices and pharmaceutics sectors. }\end{array}$ \\
\hline Resources & & - A directional wheelchair. & $\begin{array}{l}\text { - A mapping of technological resources and actors' } \\
\text { expectations and capabilities. }\end{array}$ \\
\hline
\end{tabular}

Stage 2 (beginning 2007-beginning 2008): Group of Sciences of the North

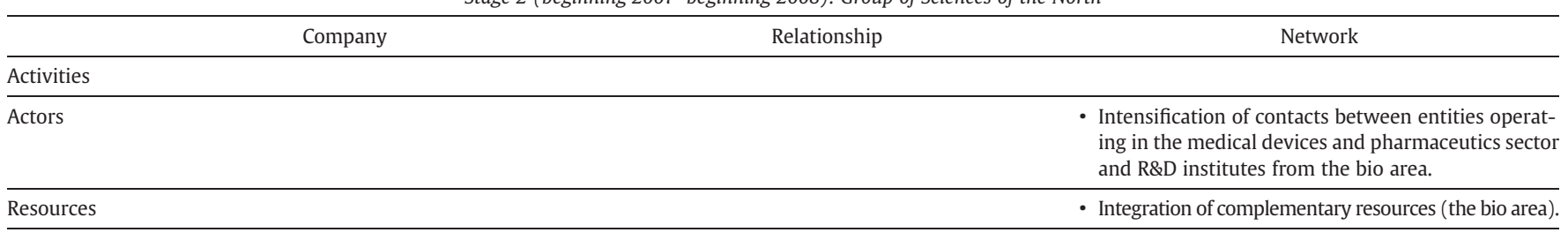

Stage 3 (beginning 2008-April 2008): HCP Founding Group

\begin{tabular}{|c|c|c|c|}
\hline & Company & Relationship & Network \\
\hline Activities & & & - Mobilizing activities. \\
\hline Actors & & $\begin{array}{l}\text { - Personal contacts between members from the } \\
\text { Founding Group and potential members. }\end{array}$ & $\begin{array}{l}\text { - Creation of an informal group (HCP Founding } \\
\text { Group) and intensification (or in some cases crea- } \\
\text { tion) of informal contacts between its } 10 \text { members. } \\
\text { - Intensification of informal contacts between the } 10 \\
\text { members of the HCP Founding Group and other na- } \\
\text { tional actors operating in the health area. }\end{array}$ \\
\hline Resources & & & $\begin{array}{l}\text { - A map of the potential members' expectations and } \\
\text { resources. }\end{array}$ \\
\hline
\end{tabular}

Stage 4 (April 2008-present): HCP

\begin{tabular}{llc}
\hline Company & Relationship & Network \\
\hline Activities & $\begin{array}{l}\text { Development of a common platform for medical } \\
\text { devices. }\end{array}$ & $\begin{array}{l}\text { Structuring projects and sub-projects between mem- } \\
\text { bers (and non-members), resembling sub-clusters. }\end{array}$ \\
\hline
\end{tabular}


Table 2 (continued)

\begin{tabular}{|c|c|c|c|}
\hline & Company & Relationship & Network \\
\hline Actors & $\begin{array}{l}\text { - Creation of a governance structure for the HCP. } \\
\text { - Fusion of the three most important research insti- } \\
\text { tutes from the north of Portugal into I3S: IPATIMUP, } \\
\text { INEB and IBMC. }\end{array}$ & $\begin{array}{l}\text { - Increasing bonding between the several actors } \\
\text { that operate along the value chain (from the re- } \\
\text { search institute, passing through the company } \\
\text { that produces the medicine and to the patient), } \\
\text { to facilitate translational research. }\end{array}$ & $\begin{array}{l}\text { - Creation of a formal group of } 55 \text { actors from the public } \\
\text { and private sphere operating in the health sector in } \\
\text { Portugal: R\&D institutes, universities, and hospitals, } \\
\text { and on a managerial level, pharmaceutics and bio- } \\
\text { technology companies, as well as medical devices } \\
\text { and services providers. } \\
\text { - Fostering networking between the actors involved in } \\
\text { the national health network of value and to promote } \\
\text { their integration into European networks of reference. } \\
\text { - Increasing density of the network. } \\
\text { - A formal group of } 100 \text { actors from the public and pri- } \\
\text { vate sphere operating in the health sector in Portugal. } \\
\text { - Intensification or creation of sub-clusters of entities op- } \\
\text { erating in the health sector. } \\
\text { - Sub-Cluster of } 30 \text { members operating in a project enti- } \\
\text { tled DO IT (sub-divided in sub-clusters in different re- } \\
\text { gions of the country, taking advantage of geographical } \\
\text { proximity and its advantage for carrying out in a sys- } \\
\text { tematic way translational research). } \\
\text { - Sub-Cluster of } 40 \text { members operating in the AAL } \\
\text { project. }\end{array}$ \\
\hline Resources & & - Adaptation of platform used for medical devices. & $\begin{array}{l}\text { - Creation of a transversal platform of dialogue and a } \\
\text { meeting place. } \\
\text { - Informal screening of the national scientific- } \\
\text { technological offer (informal database). } \\
\text { - Increased capacity of its members. } \\
\text { - Promotion of the awareness, information and for- } \\
\text { mation on translational research (TR) and technolo- } \\
\text { gy transfer/intellectual property (TT/IP) of those } \\
\text { actors involved in the health value network and of } \\
\text { legislators and decision makers. } \\
\text { - Definition of guidelines and recommendations for } \\
\text { translational research and technology transfer/ in- } \\
\text { tellectual property, based on good practices and } \\
\text { cases of success to foster the mobilization of actors } \\
\text { for involvement in projects. } \\
\text { - Promotion of members' access to better services re- } \\
\text { garding intellectual property. } \\
\text { - Creation of a bio-base. } \\
\text { - Creation of a platform common to all medical devices. }\end{array}$ \\
\hline
\end{tabular}

through factors associated with multiple theories: network, resourcedependence, and social exchange theory, homophily, proximity, and embeddedness factors, path-dependence, and cluster theory.

The next stage transition is dependent on a much smaller number of explanatory concepts. In the development towards the Group of Sciences of the North (stage 2), resource dependencies feature strongly: the recognition (during stage 1 ) that the bio-area resources were necessary as complementary resources drove activities towards forming the new cluster, also helped by pre-existing exchange ties with bio-actors. As such, heterophily characterized the choice of new participants in the cluster, with actor proximity (north of Portugal) still preserved. Therefore, some aspects of path dependence exist, but as stage 2 represented a clear reconfiguration, evolutionary theory provides important insights into its creation. I3S was clearly an important anchor organization for this evolution, which provided institution building, talent concentration, and infrastructure resource provision functions.

Stage 3 saw the HCP Founding Group develop. Once more, this stage 2-3 transition was driven by manifold explanatory constructs, like the stage $0-1$ transition. Similarly, the reputational resource of some of the most influential members in the Portuguese health system provided an important anchor for the creation and promotion of the new cluster structure. Social exchange theory provides explanatory constructs for this phenomenon via its emphasis on strong tie connections. Diversity, i.e. heterophily, again became important in this transition process to make the shift from proximity-based decisions to inclusive ones, covering the whole of Portugal, as well as all relevant health system players (new actors such as ICT companies, or hospitals now became involved). Path dependence is not an important explanatory construct for this shift, as more intentional management and a main reconfiguration are taking place. The latter result from the partnering activities that are initiated and promoted by the key founding entities (including individuals). These immediately provided a superior research infrastructure, based on some already established collaboration patterns, but more importantly on activities for increased cooperation between the founding entities.

The formal constitution of the HCP as the result of the transition from stage 3-4 again can be explained in terms of a small number of core processes, associated with only a limited number of concepts. Resource-dependence is identified in our analysis as the main driver for the transition towards covering the whole health sector on a national level, with clearly defined sub-projects with very specific resource needs forming. Depending on these sub-projects (i.e. their structure and strategic aim), both homophily and heterophily exist in terms of choosing project partners, with some sub-projects still being dependent on entity proximity, while others are geographically dispersed. For the purpose of the building of these sub-projects, institution building activities are fostered by HCP.

\section{Main findings and implications}

\subsection{Conclusion and contributions}

This paper addresses the recent calls that have been made in services research to adopt a more inter-disciplinary approach, as well as to undertake a systemic perpective and to broaden the field of research in business-to-business contexts (Johnston, 2005; Ostrom 
Table 3

Mechanisms and factors that explain the transition between the different stages underlying the process of emergence of the HCP-a dynamic perspective.

\begin{tabular}{|c|c|c|c|c|}
\hline & Stage $0 \rightarrow$ Stage 1 & Stage $1 \rightarrow$ Stage 2 & Stage $2 \rightarrow$ Stage 3 & Stage $3 \rightarrow$ Stage 4 \\
\hline $\begin{array}{l}\text { Reasons for } \\
\text { network } \\
\text { formation }\end{array}$ & $\begin{array}{l}\text { - NET: health related area identified as } \\
\text { the most 'powerful' sector in the north } \\
\text { of Portugal, with the strongest poten- } \\
\text { tial for development (identified as a } \\
\text { 'priority' area for development). } \\
\text { - RDT: strong interdependence between } \\
\text { traditional sectors and research institu- } \\
\text { tions/universities for the development } \\
\text { of medical devices; } \\
\text { - SET: benefits resulting from a close as- } \\
\text { sociation between companies in the } \\
\text { medical devices and pharmaceuticals } \\
\text { areas in the north of Portugal; } \\
\text { Getting the actors working closer } \\
\text { together in a regional health cluster } \\
\text { would result in a greater consistency in } \\
\text { the sector and in the region of the } \\
\text { northern of Portugal. }\end{array}$ & $\begin{array}{l}\text { - RDT: the information collected by the } \\
\text { GDMF members in Stage } 1 \text { allowed } \\
\text { recognizing the bio-area as an impor- } \\
\text { tant source of resources for the devel- } \\
\text { opment of the health sector in the } \\
\text { north of Portugal. } \\
\text { - SET: strong social inter-linkage be- } \\
\text { tween the members of GDMF and ac- } \\
\text { tors from the bio-area. }\end{array}$ & $\begin{array}{l}\text { - NET: some of the most influential } \\
\text { members in the health sector in Por- } \\
\text { tugal realize that the creation of a na- } \\
\text { tional cluster should be promoted. } \\
\text { - SET: personal connections between the } \\
\text { national Portuguese key players in the } \\
\text { health sector set the possibility to } \\
\text { work together towards a common aim. }\end{array}$ & $\begin{array}{l}\text { RDT: complementarity of re- } \\
\text { sources held by entities acting in } \\
\text { the health sector on a national } \\
\text { scale and on a sub-project level. }\end{array}$ \\
\hline $\begin{array}{l}\text { Choice of } \\
\text { network } \\
\text { partners }\end{array}$ & $\begin{array}{l}\text { - Homophily: the formed group joins } \\
\text { entities that were involved in similar } \\
\text { activities (medical devices and phar- } \\
\text { maceutical products). } \\
\text { - Proximity: the entities are geographi- } \\
\text { cally close or similar from a location } \\
\text { perspective as they are all located in } \\
\text { the north of Portugal. } \\
\text { Embeddedness mechanisms: the selec- } \\
\text { tion of the entities that joined the } \\
\text { group are strongly conditioned by the } \\
\text { previously existing alliances and col- } \\
\text { laboration agreements. }\end{array}$ & $\begin{array}{l}\text { - Heterophily: entities from a different } \\
\text { but complementary health area (and } \\
\text { resources) are invited to join the } \\
\text { group. } \\
\text { - Proximity: the invited entities were } \\
\text { concentrated in the same region as } \\
\text { the other entities from GDMF. } \\
\text { Embeddedness mechanisms: some of } \\
\text { entities included in the GDMF were } \\
\text { already collaborating with the enti- } \\
\text { ties that joined the group at Stage } 2 \text {. }\end{array}$ & $\begin{array}{l}\text { - Diversity: with the idea of having a } \\
\text { national cluster, entities related to the } \\
\text { heath sector but that are involved in } \\
\text { business activities of diverse nature } \\
\text { (i.e., IT services, hospitals, consultancy } \\
\text { companies), are to be included in the } \\
\text { same group. }\end{array}$ & $\begin{array}{l}\text { Homophily: some of the } \\
\text { sub-projects are to be developed } \\
\text { based on similarity between mem- } \\
\text { bers. } \\
\text { - Heterophily: some of the } \\
\text { sub-projects are to be developed } \\
\text { based on the difference between } \\
\text { members. } \\
\text { - Proximity: some of the } \\
\text { sub-projects are to be developed } \\
\text { based on geographical proximity } \\
\text { between members. } \\
\text { Appropriateness: it is appropriate } \\
\text { for the health players in Portugal } \\
\text { to join the HCP. }\end{array}$ \\
\hline $\begin{array}{l}\text { Environmental } \\
\text { conditions }\end{array}$ & $\begin{array}{l}\text { - Path-dependence: the workshops and } \\
\text { other initiatives promoted by CCDR- } \\
\text { North lead to the initial groups' forma- } \\
\text { tion; } \\
\text { There is a strong history of collabora- } \\
\text { tion and research/production activity } \\
\text { between entities in the health area in } \\
\text { the north of Portugal. } \\
\text { - Intentional management: despite the } \\
\text { pre-existing social and business rela- } \\
\text { tionships, the group's members define } \\
\text { the scope of the formed group. }\end{array}$ & $\begin{array}{l}\text { Path-dependence: the previous alli- } \\
\text { ances and collaboration activities be- } \\
\text { tween GDMF members and the } \\
\text { entities from bio-area are funda- } \\
\text { mental for the broadening of the ini- } \\
\text { tial GDMF group. } \\
\text { - Evolutionary theory: this transition } \\
\text { represents first reconfiguration of } \\
\text { the cluster, i.e. the decision to } \\
\text { broaden the array of included enti- } \\
\text { ties and health areas by including in } \\
\text { the initial group entities from the } \\
\text { bio-area. }\end{array}$ & $\begin{array}{l}\text { - Intentional management: a group of } \\
10 \text { entities sets to mobilize other ac- } \\
\text { tors to join a national and carefully } \\
\text { planned network. } \\
\text { Evolutionary theory: this transition } \\
\text { represents the main reconfiguration } \\
\text { of the network, i.e. the decision to } \\
\text { go from a regional to a national } \\
\text { dimension. }\end{array}$ & $\begin{array}{l}\text { - Intentional management: the actors } \\
\text { get organized into a national } \\
\text { network. }\end{array}$ \\
\hline $\begin{array}{l}\text { Antecedents } \\
\text { and process } \\
\text { conditions } \\
\text { for cluster } \\
\text { formation }\end{array}$ & $\begin{array}{l}\text { - Anchor organizations: concentration in } \\
\text { the north of Portugal of reference enti- } \\
\text { ties in the health area (IPATIMUP, } \\
\text { IBMC, INEB, Universidade of Porto, } \\
\text { Universidade of Minho, and specially } \\
\text { BIAL) - strong reputation and credibil- } \\
\text { ity, and networked structure. } \\
\text { - Building institutions: CCDR-North and } \\
\text { BIAL plays a crucial facilitating role in } \\
\text { the creation of the group: CCDR- } \\
\text { North identifies the key actors and got } \\
\text { them talking, while BIAL is one of the } \\
\text { key actors in the health sector of the } \\
\text { region also facilitating the whole crea- } \\
\text { tion process of GDMF. } \\
\text { - Talent concentration: the anchor entities } \\
\text { identified above act as 'magnet organi- } \\
\text { zations' for working opportunities; } \\
\text { The north of Portugal is characterized } \\
\text { by an intensive research and training } \\
\text { programs at universities, as well as a } \\
\text { strong collaboration between industry } \\
\text { and universities; } \\
\text { Region with the most dynamic center of } \\
\text { entities involved in the medical devices } \\
\text { and pharmaceutical sectors. } \\
\text { - Research infra-structure: strong } \\
\text { network of universities and research }\end{array}$ & $\begin{array}{l}\text { - Anchor organizations: the } \\
\text { mega-research institute known as I3S } \\
\text { is a point of reference in the health } \\
\text { sector in the north of Portugal. } \\
\text { - Building institutions: I3S promotes } \\
\text { collective learning by integrating the } \\
\text { three main research institutes in the } \\
\text { bio-area in the north of Portugal. } \\
\text { - Talent concentration: I3S attracts re- } \\
\text { searchers in the bio-area. } \\
\text { - Research infra-structure: I3S strongly } \\
\text { promotes the region's research } \\
\text { infra-structures. } \\
\text { - Proximity and geographical distance: } \\
\text { the entities from the bio-area that } \\
\text { joined the GDMF group are in the } \\
\text { same physical area as the latter. } \\
\text { - Level of collaboration: strong collabo- } \\
\text { ration between research institutes in } \\
\text { the bio-area. }\end{array}$ & $\begin{array}{l}\text { - Building organizations: mobilizing role } \\
\text { played by Founding Group: the phar- } \\
\text { maceutical company BIAL, the group } \\
\text { or research institutes IPATIMUP, IBMC } \\
\text { and INEB (i.e., I3S), INL - International } \\
\text { Iberian Nanotechnology Laboratory, } \\
\text { Universidade of Minho and } \\
\text { Universidade of Porto, CNC, IMM, } \\
\text { Hovione (a company operating in the } \\
\text { pharmaceutical ingredients business) } \\
\text { and CCRN-North; } \\
\text { The Medicon Valley Alliance would } \\
\text { also play a crucial role for } \\
\text { benchmarking; } \\
\text { I3S would play an exemplary role, } \\
\text { showing how it is possible to get enti- } \\
\text { ties in the health sector collaborating } \\
\text { in a successful manner. } \\
\text { - Research infra-structure: the idea for a } \\
\text { national cluster would allow capitaliz- } \\
\text { ing on the high quality scientific } \\
\text { knowledge that was being produced in } \\
\text { Portugal, as well as on the significant } \\
\text { body of research. } \\
\text { - Level of collaboration: there was some } \\
\text { previous collaboration between health } \\
\text { players across the country; } \\
\text { The national cluster would promote a }\end{array}$ & $\begin{array}{l}\text { - Anchor organizations: BIAL and } \\
\text { CCDR-North continue having } \\
\text { the role of conferring credibility } \\
\text { to the created group. } \\
\text { - Building institutions: HCP promotes } \\
\text { networking between members, as } \\
\text { well as alignment between mem- } \\
\text { bers' cognitive frameworks and } \\
\text { initiatives, and setting collective } \\
\text { standards. }\end{array}$ \\
\hline
\end{tabular}


Table 3 (continued)

\begin{tabular}{|c|c|c|c|}
\hline Stage $0 \rightarrow$ Stage 1 & Stage $1 \rightarrow$ Stage 2 & Stage $2 \rightarrow$ Stage 3 & Stage $3 \rightarrow$ Stage 4 \\
\hline $\begin{array}{l}\text { centers in the north of Portugal, } \\
\text { reflecting a source of talent and } \\
\text { attracting investment; } \\
\text { Public initiatives to promote research; } \\
\text { infra-structures. } \\
\text { - Entrepreneurial organizations: strong } \\
\text { entrepreneurial tradition with spin- } \\
\text { offs from both industry and universi- } \\
\text { ties. } \\
\text { - Proximity and geographical distance: } \\
\text { strong critical mass in the north of Por- } \\
\text { tugal of entities developing business } \\
\text { activity in the medical devices and } \\
\text { pharmaceutical sectors, facilitating } \\
\text { the exploitation of synergies and } \\
\text { attracting investment. } \\
\text { - Level of innovativeness: integration be- } \\
\text { tween highly qualified art-workers } \\
\text { from traditional industries and high- } \\
\text { tech industries/institutions (e.g., appli- } \\
\text { cation of textile products to medical } \\
\text { devices). } \\
\text { - Level of collaboration: strong collabora- } \\
\text { tion between industry and universities } \\
\text { embodied in activities involving tradi- } \\
\text { tional industries, labs, universities, hos- } \\
\text { pitals and health related centers. }\end{array}$ & & $\begin{array}{l}\text { more intensive collaboration between } \\
\text { actors of diverse nature (by getting } \\
\text { involved in translational research } \\
\text { activities). }\end{array}$ & \\
\hline
\end{tabular}

et al., 2010). This was accomplished by studying a specific aspect of business service networks (Morgan et al., 2007), namely their process of emergence. Considering the limited and scattered research that has so far been conducted on both business service networks, this paper also adds to this growing body of knowledge.

In order to understand the process of emergence of business service networks, while drawing on previous research from other bodies of literature, we have developed a framework of analysis. Our empirical findings show that there is a process of shaping and reconfiguration underlying the creation of such networks, and that, contrary to what the extant bodies of literature usually claim, there is not one sole or predominant theory that can explain the process; instead, a diverse combination of different theories are shown to have good explanatory power at different stages of the process. For example, stage 0 is best explained by referring to cluster formation concepts (such as the importance of anchor organizations, talent concentration, and existing geographical research infrastructure), all providing evidence for a path-dependency argument. The transformation to stage 1 was based on resource homophily, defined by institution building around similarly structured organizations. On the other hand, heterophily then provided the impetus for the transformation process resulting in stage 2 . Scale considerations were important for stage 3 , as well as institution building processes, and stage 4 continued this through a process characterized by path-dependencies (especially based on the developments in the previous stages), and heterophily in terms of business partner selection. Thus, environmental aspects only explain part of the stage-based transformations, while other concepts of cluster formation, including managerial choices, supplement the explanatory framework in specific stages.

Therefore, one contribution of the study is that it shows how a combinatorial logic which considers several different theories from different bodies of literature can lead to an insightful understanding of the process of emergence of businesses service networks. This is in line with the work of Powell et al. (2005) on network dynamics: the authors showed how different rules of affiliation that reflect on how partners are chosen, apply at different stages of the evolution process of inter-organizational networks, thus shaping that evolution. As the authors put it, "we do not expect that one mechanism dominates at all the time periods and exerts equal gravitational pull on every participant. The very essence of dynamic systems is that they change continually over time" (p. 8). Powell et al. (2005) illustrated how homophily, follow-the-trend or multi-connectivity principles come in at different stages of the inter-organizational networks evolution. While these authors' work focuses solely on the aspect of partner selection, and looks at the whole process of evolution of a network, our research looked uniquely at the process of emergence of networks; however, we were also interested in other aspects regarding network creation, namely the reasons networks are formed, and how environmental conditions affect the formation and antecedents of network creation.

The INA (specifically the dynamic AAR analysis) plays an important role for a systematized understanding of business service networks throughout their process of development. INA, which is based on theory developed for industrial networks (Easton, 1992; Håkansson et al., 2009), provides appropriate insights for services-related case studies in terms of understanding the morphology of the network structures as outcomes of different transformation stages: the collaborative and co-creational character of services is conceptually complementary to INA concepts.

Moreover, our case study illustrates how the emergence of business service networks may benefit from a procedural, evolutionary approach. This corroborates Gulati and Gargiulo's (1999) research on the origins of inter-organizational networks: these authors characterize the "emergence of alliances networks as a dynamic process", the result of "inter-organizational networks [being] evolutionary products of embedded organizational action" (p. 1441). This evolutionary perspective was also adopted by other authors not specifically in relation to the stage of emergence of the network, but instead including the following stage of development: as Powell et al. (2005, p. 9) put it, "network expansion follows a process". Dyer and Nobeoka (2000) also illustrated the evolutionary nature of inter-organizational networks by showing how effective learning in a network is promoted by the strengthening of initially weak ties among network members or actors.

Furthermore, our case analysis qualifies the self-perception of the involved actors who see the HCP formation as a 'big bang' approach, i.e., shaped and implemented during a relatively short decision-making phase in 2008. However, path-dependencies are clearly visible and go back to the resource constellations (as captured through the AAR analysis) of around 2005. Nevertheless, we also found clear indications in our 
analysis of discontinuities in the development process, i.e., path dependencies are broken and other explanatory concepts come into play. Therefore, clear yet temporally overlapping stages emerge from the analysis, with pronounced decision points linked to managerial intent: from local to national, or from specific areas of the health services to an overall health network. These discontinuities are linked to the formation of new network insight through which inter-organizationally overlapping cognitive belief systems emerge. Furthermore, the analysis of the morphologies of the network configurations in the different development stages shows that initially company/actor level changes are important, while in the latter stages relational and network changes become more pronounced. These findings provide evidence for the need of a wider or longitudinal analysis design which covers more than just the direct service network formation activities in order to capture shaping and priming processes and structures.

\subsection{Implications and limitations}

This study provides researchers, as well as managers, net orchestrators and policy makers, with an inter-disciplinary device that can help them understand how the creation of business service networks can be promoted or facilitated by specific actions or environmental conditions. While the main contributions at a research and theoretical level have been discussed above, in this section we look in further detail at the managerial implications of this investigation.

From the perspective of firm managers, this study identifies the diversity of factors that may condition the inclusion of firms in specific (business service) networks, such as social inter-linkages and personal connections (e.g., key players' constellations in the Portuguese health sector), and complementarity of resources within specific sub-clusters. The awareness of these conditioning factors may result, for example, in a stronger willingness by firms to engage in (social) networking efforts, and to collect further information to identify matching between companies' needs, resources, or strategic fit. Given the competitive edge associated with network embeddedness and inter-firm collaboration (Flint, 1997), this study may motivate firms to further engage in multiple activities, which may increase their attractiveness to other firms.

This paper also has substantial implications for net orchestrators. The findings from the research were discussed with the HCP management team, which recognized that despite its in-depth knowledge of the HCP creation process, it did not hold an overall picture of the multiple factors that contributed or affected the net creation. It shows, for example, how in different moments in time different actors look for different things when joining an intentionally created network as in some situations in some occasions homophily principles prevailed, while in other situations actors were looking for partners with different features). It also creates awareness of the important role that some actors may play in different stages of the creation process. For example, in our case the 'net initiator' (CCDR-North) was a public entity. This entity began by raising awareness among potential members regarding the likely benefits from the creation of a wider network structure. Consequently, after the initial formation stages, CCDR-North was instrumental in coordinating efforts with the main 'net orchestrator' or facilitator (the HCP management team) to develop the overall project. This joint effort proved crucial for the growth and sustainability of the HCP. This study has therefore provided net orchestrators, and specifically the HCP management team, with a broader and comprehensive perception of the multiple factors that condition net creation and management. In an era where collective action is acquiring a central role in the economic development plan for most European countries, knowing how these networks can be created is fundamental (OECD, 2007).

Finally, policy makers also benefit from this study as it uncovers the array of mechanisms that policy makers can put into place to promote (business network) formation that aims at service innovation, a key aspect in nations' growth and competitiveness (Spohrer \& Maglio, 2008). For example, by funding or by providing benefits (e.g., tax exemption) to what are considered anchor organizations in a specific sector and/or region, policy makers are creating a 'magnet effect' for leading organizations and specialized workers, creating conditions for inter-firm collaboration and net creation. In our case, the concentration in the north of Portugal of anchor organizations such as IPATIMUP, IBMC and others, provided credibility and reputation to the health sector in that specific region and attracted other companies from the sector to that location. The creation of research infrastructures and the promotion of a stronger collaboration between industry and universities can also play a key role in the creation of nets of collaboration and innovation efforts.

The main limitation of this project lies in using an individual case study in the empirical analysis. However, we believe that the richness of the selected case and the depth of analysis that was accomplished by combining multiple theories and complementary theorizing strategies (Langley, 1999), make the case valuable on its own for this process-based research (Bidart et al., 2012). Even richer insights could be achieved if a multiple case-study design would have been adapted (Yin, 1994). This would have allowed a comparative analysis between networks with different characteristics. A suggestion for future research would be to compare the process of emergence of a 'bottom-up' business service network like the one presented here (Roseira et al., 2009), with a 'top-down' or orchestrated one (Dhanaraj \& Parkhe, 2006).

This research is part of a bigger project, which aims at providing a richer understanding of business service networks. The first stage was based on the retrospective exploratory case-study of the HCP, a network which is still in its infancy. While this stage relied on understanding how these networks 'emerge or are created', the second stage should focus on how they 'work'. The HCP constitutes a rich case example of a fast-changing collaborative business service network and thus, further research, namely of a longitudinal and multi-level nature, is appropriate. Given the suitability shown by this study of the INA approach to study business service networks, we suggest that the investigation of interactions and relationships between the actors that are part of such networks undertakes this same approach. All actors/members of the HCP (around 100 companies and organizations) could be covered in this study, including multiple respondents per actor. A structured analysis of interactions and relationships/tie strengths, with the usage of social network analysis (Scott, 2000), would allow understanding business service networks configuration evolution vis-à-vis performance (i.e., multi-level analysis). Taking the analysis to a mesolevel by exploring the configurations and processes within each sub-network or project within the HCP would further enhance the network perspective.

\section{References}

Ahuja, G. (2000). The duality of collaboration: Inducements and opportunities in the formation of interfirm linkages. Strategic Management Journal, 21(3), 317-343.

Aldrich, H., Rosen, B., \& Woodward, W. (1987). The impact of social networks of social networks on business foundings and profit: A longitudinal study. In N. Churchill, J. Hornaday, B. Kirchoff, O. Krasner, \& K. Vesper (Eds.), Frontiers of Entrepreneurship Research (pp. 154-168) Wellesley, MA: Babson College.

Andersen, E., \& Teubal, M. (1999). High-tech cluster creation and cluster re-configuration-a systems and policy perspective. DRUIUD Meeting on National Innovation Systems, Industrial Dynamics and Innovation Policy, Rebild, June 9-12.

Araújo, L., \& Harrison, D. (2002). Path dependence, agency and technological evolution. Technology Analysis \& Strategic Management, 14(1), 5-19.

Armistead, C., \& Machin, S. (1998). Business process management: Implications for productivity in multi-stage service networks. International Journal of Service Industry Management, 9(4), 323-336.

Arthur, W. (1994). Increasing returns and path dependence in the economy. Ann Arbor: University of Michigan Press.

Avnimelech, G., \& Teubal, M. (2004). Venture capital start-up co-evolution and the emergence \& development of Israel's new high tech cluster. Economics of Innovation and New Technology, 13(1), 33-60.

Avnimelech, G., \& Teubal, M. (2008). Evolutionary targeting. Journal of Evolutionary Economics, 18(2), 151-166. 
Axelsson, B., \& Easton, G. (1992). Industrial networks: A new view of reality. New York and London: Routledge.

Ballantyne, D. (2004). Dialogue and its role in the development of relationship specific knowledge. The Journal of Business and Industrial Marketing, 19(2), 114-123.

Ballantyne, D., \& Varey, R. J. (2006). Creating value-in-use through marketing interaction: The exchange logic of relating, communicating and knowing. Marketing Theory, 6(3), 335-348.

Bidart, C., Longo, M. E., \& Mendez, A. (2012). Time and process: An operational framework for processual analysis. European Sociological Review, 28, 1-9.

Bienenstock, E., \& Bonacich, P. (1992). The core as solution to exclusionary networks. Social Networks, 14(3/4), 231-244.

Bienenstock, E., \& Bonacich, P. (1997). Network exchange as a cooperative game. Rationality and Society, 9(1), 37-65.

Birley, S. (1985). The role of networks in the entrepreneurial process. Journal of Business Venturing, 1(1), 107-117.

Bitner, M., \& Brown, S. (2006). The evolution and discovery of services science in business schools. Communications of the ACM, 49(7), 73-78.

Bitner, M., \& Brown, S. (2008). The service imperative. Business Horizons, 51(1), 39-46.

Blau, P. (1964). Exchange and power in social life. New York: Wiley.

Boschma, R., \& Wenting, R. (2007). The spatial evolution of the British automobile industry: Does location matter? Industrial and Corporate Change, 16(2), 213-238.

Bramwell, A., \& Wolfe, D. (2008). Universities and regional economic development: The entrepreneurial University of Waterloo. Research Policy, 37(8), 1175-1187.

Brass, D. (1995). A social network perspective on human resources management. Research in Personnel and Human Resources Management, 13, 39-79.

Brenner, T. (2005). Innovation and cooperation during the emergence of local industrial clusters: An empirical study in Germany. European Planning Studies, 13(6), 921-938.

Bresnahan, T., Gambardella, A., \& Saxenian, A. (2001). 'Old economy' inputs for 'new economy' outcomes: Cluster formation in the new Silicon Valleys. Industrial and Corporate Change, 10(4), 835-860.

Briggs, E., \& Griaffe, D. (2010). Service performance-loyalty intentions link in a business-to-business context: The role of relational exchange outcomes and customer characteristics. Journal of Service Research, 13(1), 37-51.

Brito, C. (2001). Towards an institutional theory of the dynamics of industrial networks. The Journal of Business and Industrial Marketing, 16(3), 150-166.

Byrne, D. (1971). The attraction paradigm. New York: Academic Press.

Camagni, R. (1995). The concept of innovative milieu and its relevance for public policies in European lagging regions. Papers in Regional Science, 74(4), 317-340.

Capecchi, V. (1992). A history of flexible specialization and industrial districts in Emilia Romagna. In F. Pyke, G. Becattini, \& W. Sengenberger (Eds.), Industrial districts and inter-firm co-operation in Italy (pp. 20-36) Geneva: International Institute for Labour Studies.

Cohen, W., \& Levinthal, D. (1990). Absorptive capacity: A new perspective on learning and innovation. Administrative Science Quarterly, Special Issue: Technology, Organizations, and Innovation, 35(1), 128-152.

Conrath, D. (1973). Communication environment and its relationship to organizational structure. Management Science, 20(4), 586-603.

Cook, K. (1977). Exchange and power in networks of interorganizational relations. The Sociological Quarterly, 18(1), 62-82.

Cooke, P. (2002). Regional innovation systems: General findings and some new evidence from biotechnology clusters. The Journal of Technology Transfer, 27(1), 133-145.

Cova, B., \& Salle, R. (2008). Marketing solutions in accordance with S-D logic: Co-creating value with customer network actors. Industrial Marketing Management, 37(3), 270-277.

Cravens, D., \& Piercy, N. (1994). Relationship marketing and collaborative networks in service organizations. International Journal of Service Industry Management, 5(5), 39-53.

Dhanaraj, C., \& Parkhe, A. (2006). Orchestrating innovation networks. Academy of Management Review, 31(3), 659-669.

DiMaggio, P., \& Powell, W. (1983). The iron cage revisited: Institutional isomorphism and collective rationality in organizational fields. American Sociological Review, 48(2), 147-160.

Doorn, J. (2008). Is there a halo effect in satisfaction formation in business-to-business services? Journal of Service Research, 11(2), 124-141.

Doz, Y., Olk, P., \& Smith Ring, P. (2000). Formation processes of R\&D consortia: Which path to take? Where does it lead? Strategic Management Journal, 21(3), 239-266.

Dubois, A., \& Araújo, L. (2007). Case research in purchasing and supply management: Opportunities and challenges. Journal of Purchasing and Supply Management, 13(3), 170-181.

Dubois, A., \& Gilbert, M. (2010). From complexity to transparency: Managing the interplay between theory, method and empirical phenomena in IMM case studies. Industrial Marketing Management, 39(1), 129-136.

Dyer, J., \& Nobeoka, K. (2000). Creating and managing a high performance knowledgesharing network: The Toyota case. Strategic Management Journal, 21(3), 345-367.

Easton, G. (1992). Industrial networks: A review. In B. Axelsson, \& G. Easton (Eds.), Industrial networks: A new view of reality (pp. 3-27) London: Routledge.

Easton, G. (1995). Methodology and industrial networks. In K. Möller, \& D. Wilson (Eds.), Business marketing: An interaction and network perspective (pp. 411-492) Massachusetts: Kluwer Academic Publishers.

Easton, G., Wilkinson, I., \& Georgieva, K. (1997). On the edge of chaos: Towards evolutionary models of industrial networks. In H. Gemunden, T. Ritter, \& A. Walter (Eds.), Relationship and networks in international markets (pp. 273-293) Oxford: Elsevier/Pergamon.

Edvardsson, B., Gustafsson, A., \& Enquist, B. (2006). Success factors in new service development and value creation through services. In D. Spath, \& K. -P. Fähnrich (Eds.), Advances in services innovations. New York: Springer.
Emerson, R. (1962). Power-dependence relations. American Sociological Review, 27(1), 31-41.

Emerson, R. (1972). Exchange theory, part 1: A psychological basis for social exchange. In J. Berger, M. Zelditch, \& B. Anderson (Eds.), Sociological theories in progress, Vol. 2. (pp. 58-87)Boston, MA: Houghton Mifflin.

Feldman, M., Francis, J., \& Bercovitz, J. (2005). Creating a cluster while building a firm: Entrepreneurs and the formation of industrial clusters. Regional Studies, 39(1), 129-141.

Fereday, J., \& Muir-Cochrane, M. (2006). Demonstrating rigor using thematic analysis: A hybrid approach of inductive and deductive coding and theme development. International Journal of Qualitative Methods, 5(1), 80-92.

Festinger, L. (1954). A theory of social comparison processes. Human relations, Vol. VII. (pp. 114-140).

Flint, D. (1997). Customer value change in industrial marketing relationships-a call for new strategies and research. Industrial Marketing Management, 26(2), 163-175.

Ford, D. (2011). IMP and service-dominant logic: Divergence, convergence and development. Industrial Marketing Management, 40(2), 231-239.

Ford, D., Gadde, L. -E., Håkansson, H., \& Snehota, I. (2003). Managing business relationships (2nd ed.). London: John Wiley \& Sons Ltd.

Ford, D., \& Håkansson, H. (2006). The idea of interaction. The IMP Journal, 1(1), 4-27.

Gertler, M., \& Vinodrai, T. (2009). Life sciences and regional innovation: One path or many? European Planning Studies, 17(2), 235-261.

Gibbert, M., Ruigrok, W., \& Wicki, B. (2008). What passes as a rigorous case study? Strategic Management Journal, 29, 1465-1474.

Gorman, S. (1990). A mode of perceived communication in collective networks. Human Communication Research, 16(4), 582-602.

Granovetter, M. (1973). The strength of weak ties. The American Journal of Sociology, $78(6), 1360-1380$

Granovetter, M. (1992). Problems of explanation in economic sociology. In N. Nhoria, \& R. Eccles (Eds.), Networks and organizations: Structure, form and action. Boston: Harvard Business School Press.

Gulati, R. (1998). Alliances and networks. Strategic Management Journal, 19(4), 293-317.

Gulati, R., \& Gargiulo, M. (1999). Where do interorganizational networks come from? The American Journal of Sociology, 104(5), 1439-1493.

Gulati, R., Nohria, N., \& Zaheer, A. (2000). Strategic networks. Strategic Management Journal, 21(3), 203-215.

Gummesson, E. (2003). All research is interpretive! The Journal of Business and Industrial Marketing, 18(6), 482-492.

Gummesson, E. (2008). Extending the service-dominant logic: From customer centricity to balanced centricity. Journal of the Academy of Marketing Science, 36(1), 15-17.

Håkansson, H., Ford, D., Gadde, L. -G., Snehota, I., \& Waluszewski, A. (2009). Business in networks. Chichester: John Wiley.

Håkansson, H., \& Johanson, J. (1992). A model for industrial networks. In B. Axelsson, \& G. Easton (Eds.), Industrial networks-a new view of reality (pp. 28-34) London and New York: Routledge.

Håkansson, H., \& Snehota, I. (1989). No business is an island: The network concept of business strategy. Scandinavian Journal of Management, 5(3), 187-200.

Håkansson, H., \& Snehota, I. (1995). Developing relationships in business networks. London and New York: Routledge.

Halinen, A., \& Törnroos, J.A. (2005). Using case methods in the study of contemporary business networks. Journal of Business Research, 58(9), 1285-1297.

Harrison, R., Cooper, S., \& Mason, C. (2004). Entrepreneurial activity and the dynamics of technology-based cluster development: The case of Ottawa. Urban Studies, 41(5-6), 1045-1070.

Hassink, R. (2005). How to unlock regional economies from path dependency? From learning region to learning cluster. European Planning Studies, 13(4), 522-535.

Health Cluster Portugal (2009a). Estratégia e Programa de Acção [Strategy and action plan]. 24 pp., Retrieved 24th January 2012, from http://healthportugal.com/ Quem\%20somos/documentos/eec-hcp-prog-accao-maio09-vsite.pdf

Health Cluster Portugal (2009b). Estatutos [Statutes]. 11 pp., Retrieved 24th January 2012 from http://healthportugal.com/Quem\%20somos/documentos/hcp-apcs-estatutos.pdf

Heider, F. (1958). The psychology on interpersonal relations. New York: Wiley.

Heskett, J., Jones, T., Loveman, G., Sasser, W., \& Schlesinger, L. (1994). Putting the service-profit chain to work. Harvard Business Review, 72(2), 164-174.

Heskett, J., \& Sasser, E. (2010). The service profit chain: From satisfaction to ownership. In B. Hefley, \& W. Murphy (Eds.), Handbook of service science-service science: Research and innovations in the service economy (pp. 19-29) Harvard: Springer.

Hite, J., \& Hesterly, W. (2001). The evolution of firm networks: From emergence to early growth of the firm. Strategic Management Journal, 22(3), 275-286.

Hodgson, G. (1993). Economics and evolution: Bringing life back into economics. Cambridge, UK and Ann Arbor: MI: Polity Press and University of Michigan Press.

Homans, G. (1950). The human group. New York: Harcourt Brace.

Homans, G. (1974). Social behavior: Its elementary forms. New York: Harcourt Brace.

Huber, G. P., \& Power, D. J. (1985). Retrospective reports of strategic-level managers: Guidelines for increasing their accuracy. Strategic Management Journal, 6(2), 171-180.

Hunt, S., \& Morgan, R. (1995). The comparative advantage theory of competition. Journal of Marketing, 59(2), 1-16.

Jamal, A., \& Anastasiadou, K. (2009). Investigating the effects of service quality dimensions and expertise on loyalty. Journal of Marketing, 43(3/4), 398-420.

Jarillo, C. (1988). On strategic networks. Strategic Management Journal, 9(1), 31-41.

Jårvensivu, T., \& Törnroos, J.-Å. (2010). Case study research with moderate constructionism: Conceptualization and practical illustration. Industrial Marketing Management, 39(1), 100-108.

Johanson, J., \& Mattsson, L. G. (1992). Network positions and strategic action-an analytical framework. In B. Axelsson, \& G. Easton (Eds.), Industrial networks: A new view of reality (pp. 205-217) London: Routledge. 
Johnson, J. (1992). Approaches to organizational communication structure. Journal of Business Research, 25(2), 99-113.

Johnston, R. (2005). Update-service operations management: From the roots up. International Journal of Operations \& Production Management, 25(12), 1298-1308.

Keiningham, T., \& Perkins-Munn, T. (2003). The impact of customer satisfaction on share-of-wallet in a business-to-business environment. Journal of Service Research, 6(1), 37-50.

Krippendorff, K. (2004). Content analysis. Thousand Oaks: Sage.

Krugman, P. (1991). Geography and trade. Cambridge, MA: MIT Press.

Langley, A. (1999). Strategies for theorizing from process data. Academy of Management Review, 24(4), 691-710.

Larson, A., \& Starr, J. (1993). A network model of organization formation. Entrepreneurship Theory and Practice, 17(2), 5-15.

Lee, R., Ginn, G., \& Naylor, G. (2009). The impact of network and environmental factors on service innovativeness. Journal of Services Marketing, 23(6), 397-406.

Liljander, V., \& Strandvik, T. (1995). The nature of customer relationships in services. In T. Swartz, D. Bowen, \& S. Brown (Eds.), Advances in services marketing and management, Vol. 4. (pp. 141-167)London: JAI Press Inc.

Lincoln, Y. S., \& Guba, E. (1985). Naturalistic enquiry. Beverly Hills, CA: Sage.

Lorenzen, M. (1998). Specialization and localized learning: Six studies on the European furniture industry. Copenhagen: Copenhagen Business School Press.

Lowe, S., \& Hwang, K. -S. (2012). A NICE agenda for IMP research. Industrial Marketing Management, 41(4), 706-714.

Lucas, M., Sands, A., \& Wolfe, D. (2009). Regional cluster in a global industry: ICT clusters in Canada. European Planning Studies, 17(2), 189-209.

Lusch, R., Vargo, S., \& Tanniru, M. (2010). Service, value networks and learning. Journa of the Academy of Marketing Science, 38(1), 19-31.

Maglio, P. P., \& Spohrer, J. (2008). Special issue on service science, management and engineering. IBM Systems Journal, 47(1), 1-192.

Martin, R., \& Sunley, P. (2006). Path dependence and regional economic evolution. Journal of Economic Geography, 6(4), 395-437.

Mattsson, L. G. (1988). Interaction strategies: A network approach. AMA Summer Marketing Educators Conference (pp. 310-315) San Francisco, California: AMA.

McPhee, R., \& Corman, S. (2011). An activity-based theory of communication networks in organizations, applied to the case of a local church. Communication Monographs, 62(2), 1-20.

McPherson, M., \& Smith-Lovin, L. (1987). Homophily in voluntary organizations: Status distance and the composition of face-to-face groups. American Sociological Review, $52(3), 370-379$

Miles, B., \& Huberman, A. M. (1994). Qualitative data analysis: A sourcebook of new methods. London: Sage Publications.

Mittal, V., Anderson, E., Sayrak, A., \& Tadikamalla, P. (2005). Dual emphasis and the long-term financial impact of customer satisfaction. Marketing Science, 24(4), $544-555$.

Mohr, L. (1982). Explaining organizational behavior. San Francisco: Jossey-Bass.

Möller, K., \& Svahn, S. (2003). Managing strategic nets: A capability perspective. Marketing Theory, 3(2), 201-226.

Monge, P., \& Contractor, N. (2003). Theories of communication networks. Oxford: Oxford University Press.

Morgan, F. (2004). Brand image formation and updating across multiple-episode experiences within service networks. (Unpublished Doctoral Dissertation). (Phoenix, AZ).

Morgan, F., Deeter-Schmelz, D., \& Moberg, C. (2007). Branding implications of partner firm-focal firm relationships in business-to-business service networks. The Journal of Business and Industrial Marketing, 22(6), 372-382.

Morgan, F., \& Tax, S. (2004). Toward a theory of service delivery networks. Working Paper. Phoenix, AZ: Arizona State University.

Mouzas, S., Henneberg, S., \& Naudé, P. (2008). Developing network insight. Industria Marketing Management, 37(2), 167-180.

Nelson, R. (1995). Recent evolutionary theorizing about economic change. Journal of Economic Literature, 33(1), 48-90.

Nohria, N. (1992). Is a network perspective a useful way of studying organisations? In N. Nohria, \& R. Eccles (Eds.), Networks and organizations: Structure, form and action. Boston, MA: Harvard Business School Press.

Nohria, N., \& Eccles, R. (1992). Networks and organizations: Structure, form and action. Boston, Massachusetts, Boston: Harvard Business School Press.

Normann, R. (2001). Reframing business: When the map changes the landscape. Chichester, England: Wiley.

Normann, R., \& Ramirez, R. (1993). From value chain to value constellation: Designing interactive strategy. Harvard Business Review, 65-77.

OECD (2007). Competitive regional clusters: National policies approaches. OECD reviews of regional innovation, Organization for Economic Co-Operation and Development. Paris: OECD.

Ostgaard, T., \& Birley, S. (1994). Personal networks and firm competitive strategy-a strategic or coincidental match? Journal of Business Venturing, 9(4), 281-305.

Ostrom, A., Bitney, J., Brown, S., Burkhard, K., Goul, M., Smith-Daniels, V., et al. (2010). Moving forward and making a difference: Research priorities for the science of service. Journal of Service Research, 13(1), 1-33.

Parasuraman, A., Zeithaml, V., \& Berry, L. (1988). Servqual: A multi-item scale for measuring consumer perception of service quality. Journal of Retailing, 64(1), 12-40.

Parasuraman, A., Zeithaml, V., \& Berry, L. (1994). Reassessment of expectations as a comparison standard in measuring service quality: Implications for further research. Journal of Marketing, 58(1), 111-124.

Parolini, C. (1999). The Value Net: A tool for competitive advantage. Chichester: John Wiley \& Sons Ltd.

Payne, A., Storbacka, K., \& Frow, P. (2008). Managing the co-creation of value. Journal of the Academy of Marketing Science, 36(1), 83-96.
Perez-Aleman, P. (2000). Learning, adjustments and economic development: Transforming firms, the state and associations in Chile. World Development, 28(1), 41-55.

Perez-Aleman, P. (2005). Cluster formation, institutions and leaning: The emergence of clusters and development in Chile. Industrial and Corporate Change, 14(4), 651-677.

Pettigrew, A. M. (1992). The character and significance of strategy process research. Strategic Management Journal, 13, 5-16 (Special Issue).

Pettigrew, A. M. (1997). What is processual analysis? Scandinavian Journal of Management, 13(4), 337-348.

Pfeffer, J., \& Salancik, G. (1978). The external control of organizations: A resource dependence perspective. New York: Harper and Row, Publishers.

Pilkington, A., \& Chai, K. -H. (2008). Research themes, concepts and relationships: A study of International Journal of Service Industry Management. International Journal of Service Industry Management, 19(1), 83-110.

Piyush, S., Jackie, L., \& Namwoon, K. (2009). Demystifying intercultural service encounters: Toward a comprehensive conceptual framework. Journal of Service Research, 12(2), 227-242.

Porter, M. (1998). Clusters and competition: New agendas for companies, governments, and institutions. In M. Porter (Ed.), On competition. Cambridge, MA: Harvard Business Review Books.

Porter, M. (2000). Location, competition, and economic development: Local clusters in a global economy. Economic Development Quarterly, 14(1), 1-21.

Powell, W., White, D., Koput, K., \& Owen-Smith, J. (2005). Network dynamics and field evolution: The growth of inter-organisational collaboration in the life sciences. The American Journal of Sociology, 110(4), 1132-1205.

Ramaseshan, B., Bejou, D., Jain, S., Mason, C., \& Pancras, J. (2006). Issues and perspectives in global customer relationship management. Journal of Service Research, 9(2), 195-207.

Ritchie, J., \& Lewis, J. (2003). Qualitative research practice: A guide for social sciences students and researchers. London: Sage Publications.

Ritter, T., \& Gemunden, H. (2003). Network competence: Its impact on innovation success and its antecedents. Journal of Business Research, 56(9), 745-755.

Ritter, T., Wilkinson, I., \& Johnston, W. (2004). Managing in complex business networks. Industrial Marketing Management, 33(3), 175-183.

Rogers, E. (2003). Diffusion of innovations. New York: The Free Press.

Roseira, C., Brito, C., \& Garrett, A. (2009). Innovation, collective action and network positioning: A case for the automotive industry. 25th Annual IMP Conference. Marseilles, France.

Rosiello, A., \& Orsenigo, L. (2008). A critical assessment of regional innovation policy in pharmaceutical biotechnology. European Planning Studies, 16(3), 337-357.

Rust, R. (2004). A call for a wider range of service research. Journal of Service Research, $6(3), 2-11$

Rust, R., \& Zahoril, A. (1993). Customer satisfaction, customer retention, and market share. Journal of Retailing, 69(2), 193-215.

Ruttan, V. (1997). Induced innovation, evolutionary theory and path dependence: Sources of technical change. The Economics Journal, 107, 1520-1529.

Ryals, L., \& Humphries, A. (2007). Managing key business-to-business relationships. Journal of Service Research, 9(4), 312-326.

Sabel, C. (1996). Learning by monitoring: The institutions of economic development. In N. Smelser, \& R. Swedberg (Eds.), Handbook of economic sociology (pp. 137-165) Princeton, NJ: Princeton University Press.

Saxenian, A. (1998). Regional systems of innovation and the blurred firm. In J. De la Mothe, \& G. Paquet (Eds.), Local and regional systems of innovation. Norwell, MA: Kluwer.

Schmitz, H., \& Nadvi, K. (1999). Clustering and industrialization: Introduction. World Development, 27(9), 1503-1514.

Scott, J. (2000). Social network analysis: A handbook (2nd ed.). London: Sage.

Sengenberger, W., \& Pyke, F. (1992). Industrial districts and local economic regeneration: Research and policy issues. In F. Pyke, \& W. Sengenberger (Eds.), Industrial districts and local economic regeneration (pp. 3-29) Geneva: International Institute for Labour Studies.

Shapira, P., \& Yountie, J. (2008). Emergence of nanodistricts in the United States: Path dependence or new opportunities? Economic Development Quarterly, 22(3), 187-199.

Shostack, G. (1985). Planning the service encounter. In J. Czepiel, M. Solomon, \& C. Surprenant (Eds.), The service encounter. New York: Lexington Books.

Spohrer, J., \& Maglio, P. (2008). The emergence of service science: Toward systematic service innovations to accelerate co-creation of value. Production and Operations Management, 17(3), 238-246.

Spohrer, J., Maglio, P., Bailey, J., \& Gruhl, D. (2007). Steps towards a science of service systems. Computer, 40(1), 71-77.

Staber, U. (1996). Accounting for variations in the performance of industrial districts: The case of Baden-Wuttemberg. International Journal of Urban E' Regional Research, 20(2), 299-316.

Syson, F., \& Perks, H. (2004). New service development: A network perspective. Journal of Services Marketing, 18(4), 255-266.

Tax, S., Brown, S., \& Chandrashekaran, M. (1998). Customer evaluations of service complaint experiences: Implications for relationship marketing. Journal of Marketing, $62(2), 60-76$.

Teubal, M., \& Andersen, E. (2000). Enterprise restructuring and embeddedness: A policy and systems perspective. Industrial and Corporate Change, 9(1), 87-111.

Tikkanen, H., Alajoutsijarvi, K., \& Tahtinen, J. (2000). The concept of satisfaction in industrial markets: A contextual perspective and a case study from the software industry. Industrial Marketing Management, 29(4), 373-386.

Tosi, H. (1992). The environment/organization/person contingency model: A Meso approach to the study of organizations. Greenwich, CT: JAI.

Turner, J. (1987). Rediscovering the social group: A self-categorization theory. Oxford: Blackwell. 
Turner, J., \& Oakes, P. (1989). Self-categorization theory and social influence. In P. Paulus (Ed.), Psychology of group influence (pp. 233-275) Hillsdale, NJ: Erlbaum.

Uzzi, B. (1997). Social structure and competition in interfirm networks: The paradox of embeddedness. Administrative Science Quarterly, 42(1), 35-67.

Van de Ven, A. (1976). On the nature, formation and maintenance of relationships amongst organizations. Academy of Management Review, 1(4), 24-36.

Van de Ven, A., \& Huber, G. P. (1990). Longitudinal field research methods for studying processes of organizational change. Organization Science, 1, 213-219.

Vandaele, D., \& Gemmel, P. (2007). Purchased business services influence downstream supply chain members. International Journal of Service Industry Management, 18(3), 307-321.

Vanhaverbeke, W., \& Cloodt, M. (2006). Open innovation in value networks. In H. Chesbrough, W. Vanhaverbeke, \& J. West (Eds.), Open innovation: Researching a new paradigm (pp. 258-281) Oxford: Oxford University Press.

Vargo, S., \& Lusch, R. (2004). Evolving to a new dominant logic for marketing. Journal of Marketing, 68(1), 1-17.

Vargo, S., \& Lusch, R. (2008). Service-dominant logic: Continuing the evolution. Journal of the Academy of Marketing Science, 36(1), 1-10.

Vázquez-Casielles, R., Álvarez, L. S., \& Martín, A. D. (2010). Perceived justice of service recovery strategies: Impact on customer satisfaction and quality relationship. Psychology and Marketing, 27(5), 487-509.
Vipraio, P. (1996). From local to global networking: The restructuring of Italian industrial districts. Journal of Industry Studies, 3, 133-151.

Walter, A. (2001). Value creation in buyer-seller relationships: Theoretical considerations and empirical results from a suppliers' perspective. Industrial Marketing Management, 30(4), 365-377.

White, H. (1981). Where do markets come from? The American Journal of Sociology, 87, 517-547.

Wolfe, D., \& Gertler, M. (2006). Local antecedents and trigger events: Policy implications and path dependence for cluster formation. In P. Braunerheim, \& M Feldman (Eds.), Industrial genesis: The emergence of technology clusters. Oxford: Oxford University Press.

Woodside, A., \& Wilson, E. (2003). Case study research methods for theory building. The Journal of Business and Industrial Marketing, 18(6/7), 493-508.

Yamagishi, T., Gilmore, M., \& Cook, K. (1988). Network connections and the distribution of power in exchange networks. The American Journal of Sociology, 93, 833-851.

Yin, R. (1994). Case study research: Design and methods (2nd ed.). London: Sage Publications.

Zolkiewski, J., Lewis, B., Yuan, F., \& Yuan, J. (2007). An assessment of customer service in business-to-business relationships. Journal of Services Marketing, 21(5), 313-325. 